
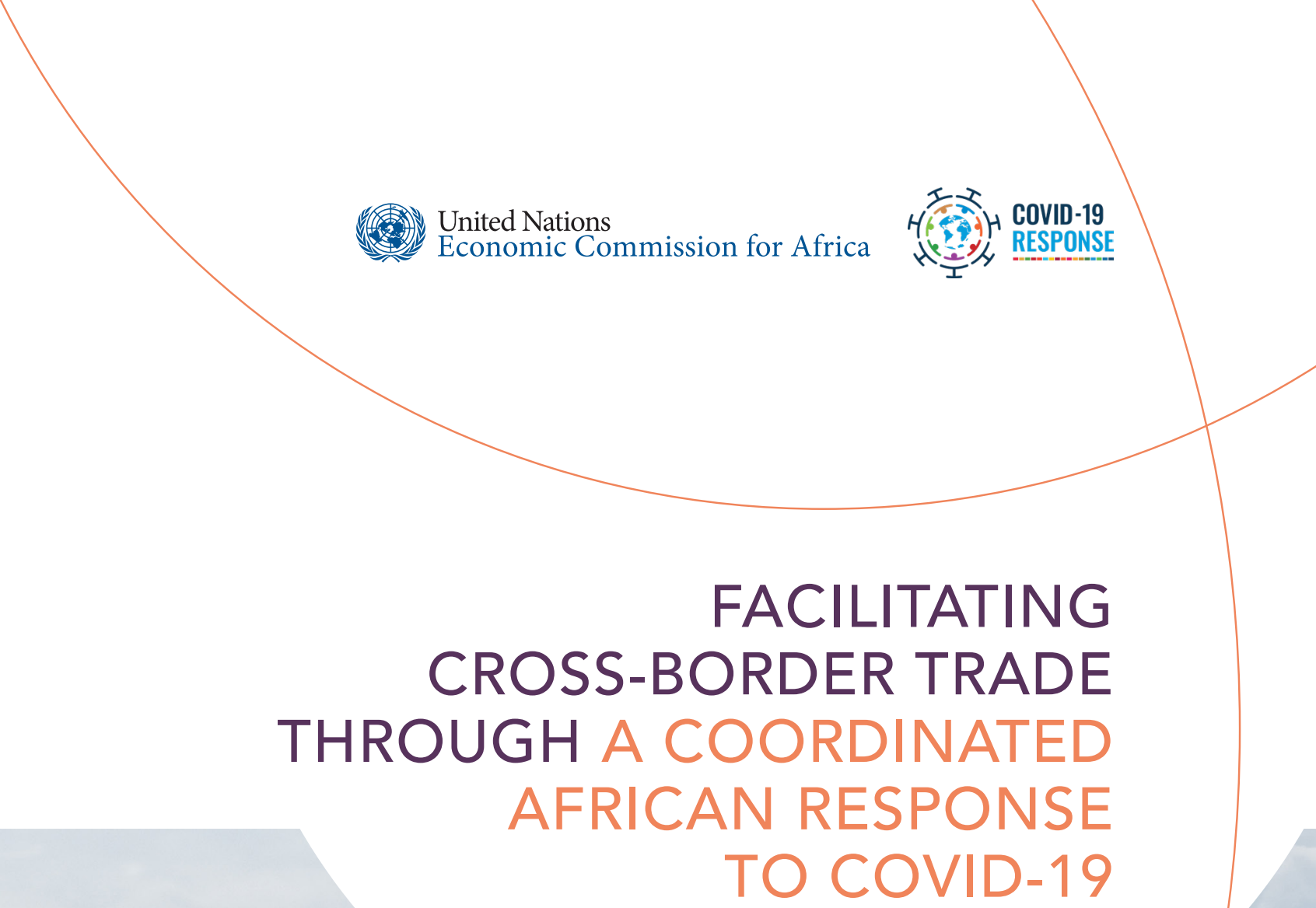

305

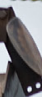





\section{FACILITATING CROSS-BORDER TRADE THROUGH A COORDINATED AFRICAN RESPONSE TO COVID-19}


To order copies of Facilitating cross-border trade through a coordinated African response to COVID-19 by the Economic Commission for Africa, please contact:

Publications and Conference Management Section

Economic Commission for Africa

P.O. Box 3001

Addis Ababa, Ethiopia

Tel: +251 11 544-9900

Fax: +251 11 551-4416

E-mail:eca-info@un.org

Web: www.uneca.org

(c) 2020 Economic Commission for Africa

Addis Ababa, Ethiopia

All rights reserved

First printing: July 2020

Material in this publication may be freely quoted or reprinted. Acknowledgement is requested, together with a copy of the publication

The designations employed in this report and the material presented in it do not imply the expression of any opinion whatsoever on the part of the Secretariat of the United Nations Economic Commission for Africa concerning the legal status of any country, territory, city or area or of its authorities, or concerning the delimitation of its frontiers or boundaries.

Designed and printed in Addis Ababa by the ECA Printing and Publishing Unit. ISO 14001:2015 certified.

Printed on chlorine free paper.

Cover photos: Shutterstock 


\section{Contents}

Acknowledgements ............................................................................................................... iv

Key action areas........................................................................................................................

COVID-19 border restrictions and regulations ............................................................... 1

COVID-19 cross-border trade challenges .......................................................................... 6

Status update: border operations and regulations across regional economic communities....................................................................................................................... 9

Community of Eastern and Southern Africa......................................................................................... 9

East African Community ...................................................................................................................................

Economic Community of West African States ..............................................................................15

Southern African Development Community.........................................................................................17

A comparison across regional economic communities of COVID-19

guidelines for the movement of goods and services ................................................... 22

COVID-19: an opportunity to overcome long-standing cross-border trade challenges ......25

Conclusion and policy recommendations .......................................................................... 28

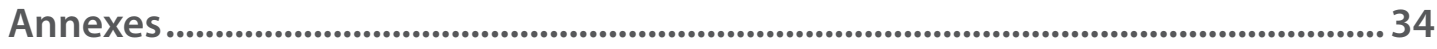

Annex I: African country imports on a monthly and quarterly basis (year-on-year percentage changes), 2020 versus 2019.......................................................................................

Annex II: African country imports on a, monthly and quarterly basis (year-on-year percentage changes), 2020 versus 2019................................................................................................. 35

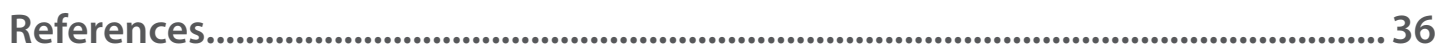




\section{Acknowledgements}

The present report was prepared under the overall guidance of the Executive Secretary of the Economic Commission for Africa (ECA), Vera Songwe, with oversight by the Director of Regional Integration and Trade Division at ECA, Stephen Karingi.

The drafting of the report was led by a Trade Policy Expert with the African Trade Policy Centre (ATPC) at ECA, Lily Sommer. Substantive contributions were provided by ECA staff, including the Coordinator of ATPC, David Luke; Chief of the Energy, Infrastructure and Services Section, Robert Lisinge; Senior Economic Affairs Officer, Soteri Gatera; and Trade Policy Experts, Jamie Macleod and Nadia Hasham.

The analysis in the report was based on data shared by a number of organizations, including the Eastern Africa Grain Council and the United Nations Conference on Trade and Development (UNCTAD).

The report was prepared for publication by the Publications and Conference Management Section of ECA. 


\section{Key action areas}

\begin{tabular}{|c|c|c|}
\hline \multirow{3}{*}{$\begin{array}{l}\text { Fast track the } \\
\text { implementation of } \\
\text { regional COVID-19 } \\
\text { guidelines to achieve } \\
\text { results on the ground }\end{array}$} & & $\begin{array}{l}\text { Regional economic communities should establish committees } \\
\text { to coordinate the implementation of guidelines and facilitate } \\
\text { the resolution of operational issues at borders during the } \\
\text { coronavirus disease (COVID-19) pandemic }\end{array}$ \\
\hline & » & $\begin{array}{l}\text { Border authorities should be encouraged to develop and } \\
\text { display simple visual step-by-step guides on COVID-19 border } \\
\text { regulations for truck drivers and cross-border traders }\end{array}$ \\
\hline & $»$ & $\begin{array}{l}\text { Efforts should be made to gradually widen the scope of } \\
\text { guidelines to facilitate the movement of all (not just essential) } \\
\text { goods and services across borders, to generate business and to } \\
\text { help kick-start economic recoveries }\end{array}$ \\
\hline \multirow{3}{*}{$\begin{array}{l}\text { Provide support to } \\
\text { the African Union in } \\
\text { its efforts to develop } \\
\text { a common COVID-19 } \\
\text { protocol on trade and } \\
\text { transport, to ensure } \\
\text { coordination }\end{array}$} & $»$ & $\begin{array}{l}\text { Support should be provided to the African Union to develop a } \\
\text { common protocol. Given the overlap in membership of regional } \\
\text { economic communities and shared trade facilitation goals of } \\
\text { the African Continental Free Trade Area (AfCFTA) negotiations, a } \\
\text { common protocol is important }\end{array}$ \\
\hline & » & $\begin{array}{l}\text { The proposed protocol would be able to build upon existing } \\
\text { regional economic community guidelines and the best-practice } \\
\text { COVID-19 border regulations and interventions outlined in the } \\
\text { present report }\end{array}$ \\
\hline & » & $\begin{array}{l}\text { A common African Union COVID-19 test certificate for truck } \\
\text { drivers and crew members is required to facilitate a harmonized } \\
\text { approach across the continent to certifying COVID-19 test results }\end{array}$ \\
\hline \multirow{3}{*}{$\begin{array}{l}\text { Ensure that African } \\
\text { economies and } \\
\text { regional integration } \\
\text { are not undermined } \\
\text { by COVID-19 and } \\
\text { that the momentum } \\
\text { and ambition of the } \\
\text { AfCFTA negotiations } \\
\text { are maintained }\end{array}$} & $»$ & $\begin{array}{l}\text { A rapid and ambitious implementation of the Agreement } \\
\text { Establishing the African Continental Free Trade Area will hasten } \\
\text { economic recovery in the wake of the COVID-19 pandemic, } \\
\text { while protecting Africa against future adverse global shocks }\end{array}$ \\
\hline & $»$ & $\begin{array}{l}\text { African countries should start to implement some elements of } \\
\text { the Agreement, including the non-tariff barrier mechanism and } \\
\text { annexes on trade facilitation and customs cooperation, which } \\
\text { have already been completed }\end{array}$ \\
\hline & & $\begin{array}{l}\text { These annexes should be implemented in a manner that is } \\
\text { cognizant of the risks of unregulated movements of pathogens } \\
\text { and hazardous goods }\end{array}$ \\
\hline
\end{tabular}




$\begin{array}{lll} & \text { » } \begin{array}{l}\text { Implementation of existing trade facilitation tools should } \\ \text { be rolled out across the continent and tailored to respond to } \\ \text { COVID-19 border challenges }\end{array} \\ \begin{array}{ll}\text { Ensure that existing } \\ \text { trade facilitation }\end{array} \\ \text { tools are utilized and } \\ \text { tailored to respond } \\ \text { to COVID-19-related } \\ \text { border disruptions }\end{array} \quad \begin{aligned} & \text { Union Development Agency - New Partnership for Africa's } \\ & \text { Development (AUDA-NEPAD) traffic light system and regional } \\ & \text { transit guarantee schemes }\end{aligned}$




\section{COVID-19 border restrictions and regulations}

The coronavirus disease pandemic, while above all a public health crisis, has presented the African continent with unprecedented economic challenges. In order to contain cross-border transmission of the virus, countries have introduced various restrictions to cross-border and transit freight transportation.

Almost all African countries have now to a differing degree suspended international flights, introduced 14-day quarantine for entrants into the country, and closed land or maritime borders. As demonstrated in table 1, 38 of Africa's 54 countries have announced land closures in some form, and 17 countries have announced maritime border closures. Under a set of strict regulations, these closures are targeted at reducing the movement of people while allowing exemptions for the movement of emergency and essential freight supplies. Such regulations typically cover mandatory testing, sanitizing trucks, limiting the numbers of crew members on trucks, and designating transit resting areas.

\section{Table 1: Travel restrictions in African countries}

\begin{tabular}{|c|c|c|c|}
\hline & Flights suspended & $\begin{array}{l}\text { Land borders } \\
\text { closed }\end{array}$ & $\begin{array}{l}\text { Maritime borders } \\
\text { closed }\end{array}$ \\
\hline \multicolumn{4}{|l|}{ Algeria } \\
\hline \multicolumn{4}{|l|}{ Angola } \\
\hline \multicolumn{4}{|l|}{ Benin } \\
\hline \multicolumn{4}{|l|}{ Botswana } \\
\hline \multicolumn{4}{|l|}{ Burkina Faso } \\
\hline \multicolumn{4}{|l|}{ Burundi } \\
\hline \multicolumn{4}{|l|}{ Cameroon } \\
\hline \multicolumn{4}{|l|}{ Cabo Verde } \\
\hline \multicolumn{4}{|l|}{ Central African Republic } \\
\hline \multicolumn{4}{|l|}{ Chad } \\
\hline \multicolumn{4}{|l|}{ Comoros } \\
\hline \multicolumn{4}{|l|}{ Congo } \\
\hline \multicolumn{4}{|l|}{ Côte d'Ivoire } \\
\hline \multicolumn{4}{|l|}{ Democratic Republic of the Congo } \\
\hline \multicolumn{4}{|l|}{ Djibouti } \\
\hline \multicolumn{4}{|l|}{ Egypt } \\
\hline \multicolumn{4}{|l|}{ Equatorial Guinea } \\
\hline \multicolumn{4}{|l|}{ Eritrea } \\
\hline \multicolumn{4}{|l|}{ Eswatini } \\
\hline \multicolumn{4}{|l|}{ Ethiopia } \\
\hline \multicolumn{4}{|l|}{ Gabon } \\
\hline \multicolumn{4}{|l|}{ Gambia } \\
\hline \multicolumn{4}{|l|}{ Ghana } \\
\hline Guinea & & & \\
\hline
\end{tabular}




\begin{tabular}{|c|c|c|c|}
\hline & Flights suspended & $\begin{array}{l}\text { Land borders } \\
\text { closed }\end{array}$ & $\begin{array}{c}\text { Maritime borders } \\
\text { closed }\end{array}$ \\
\hline \multicolumn{4}{|l|}{ Guinea-Bissau } \\
\hline \multicolumn{4}{|l|}{ Kenya } \\
\hline \multicolumn{4}{|l|}{ Lesotho } \\
\hline \multicolumn{4}{|l|}{ Liberia } \\
\hline \multicolumn{4}{|l|}{ Libya } \\
\hline \multicolumn{4}{|l|}{ Madagascar } \\
\hline \multicolumn{4}{|l|}{ Malawi } \\
\hline \multicolumn{4}{|l|}{ Mali } \\
\hline \multicolumn{4}{|l|}{ Mauritania } \\
\hline \multicolumn{4}{|l|}{ Mauritius } \\
\hline \multicolumn{4}{|l|}{ Morocco } \\
\hline \multicolumn{4}{|l|}{ Mozambique } \\
\hline \multicolumn{4}{|l|}{ Namibia } \\
\hline \multicolumn{4}{|l|}{ Niger } \\
\hline \multicolumn{4}{|l|}{ Nigeria } \\
\hline \multicolumn{4}{|l|}{ Rwanda } \\
\hline \multicolumn{4}{|l|}{ Sao Tome and Principe } \\
\hline \multicolumn{4}{|l|}{ Senegal } \\
\hline \multicolumn{4}{|l|}{ Seychelles } \\
\hline \multicolumn{4}{|l|}{ Sierra Leone } \\
\hline \multicolumn{4}{|l|}{ Somalia } \\
\hline \multicolumn{4}{|l|}{ South Africa } \\
\hline \multicolumn{4}{|l|}{ South Sudan } \\
\hline \multicolumn{4}{|l|}{ Sudan } \\
\hline \multicolumn{4}{|l|}{ Togo } \\
\hline \multicolumn{4}{|l|}{ Tunisia } \\
\hline \multicolumn{4}{|l|}{ Uganda } \\
\hline \multicolumn{4}{|l|}{ United Republic of Tanzania } \\
\hline Zambia & & & \\
\hline
\end{tabular}

Source: ECA calculations are based on the World Food Programme COVID-19 World Travel Restrictions database (as at 7 June 2020).

These border restrictions and regulations have helped to minimize infections and deaths across the continent, which, as of 7 July 2020, had a total of 493,708 confirmed cases and 11,668 deaths. Such regulation, however, has had a negative impact on cross-border trade and economic activity, hindering both significantly. Furthermore, border regulations are not always well understood and, in some instances, have been inconsistently applied. This has caused confusion among many truck drivers and clashes with border authorities. In East Africa, for example, disputes have arisen that have required diplomatic intervention.

The United Nations Conference on Trade and Development (UNCTAD) reports that trade in merchandise fell globally by 5 per cent in the first quarter of the year and predicts a 27 per cent drop for the second quarter and a 20 per cent annual decline for 2020 (UNCTAD, 2020). As shown in figure I, UNCTAD preliminary data based on national statistics indicate that Africa's exports in 2020 declined by 5 per cent in February, 16 per cent in March and 32 per cent in April (compared to the same month the previous year). This demonstrates that the impact on Africa's exports worsened as both the severity and spread of COVID-19 increased across the continent, and as the decline in commodity prices worsened (figure II). Petroleum, metals and 
ores account for over 50 per cent of the value of Africa's total exports, and annex 211 shows that those African countries heavily reliant on oil exports experienced some of the largest declines in exports, including Algeria, Angola, Equatorial Guinea, Gabon and Nigeria, along with countries reliant on mineral exports such as Botswana and Namibia. As highlighted in figure III, Africa's imports similarly recorded declines of 7 per cent in March 2020 and 25 per cent in April 2020.

Intra-African exports started to decline a month after Africa's exports to the rest of the world declined: in March 2020 there was a decline of 1 per cent and, in April 2020, it was 17 per cent. One view is that this reflects the fact that COVID-19 originated in China, and spread to other important trading partners for Africa, such as the United States and a number of European countries, before reaching the African continent. The impact of the significant drop in intraAfrican exports was felt in April 2020, following the enforcement of African lockdowns, travel bans and COVID-19 border regulations in March 2020. Nevertheless, figure I indicates that intraAfrican exports have been more resilient to the twin COVID-19 and commodity price shock, than Africa's exports to the rest of the world have been. This highlights the importance of further developing competitive and diversified intra-African value chains in the future.

Cross-border trade disruptions, including such factors as a slowdown in demand, declining commodity prices, supply chain blockages, increased freight costs and export bans, are likely to have played a role in Africa's slowdown in trade. Annexes I and II present the preliminary monthly and quarterly percentage changes (year-on-year) in exports and imports of African countries for which data are available.

\section{Figure I: Africa's exports on a monthly basis (year-on-year percentage changes), 2020 compared to 2019}

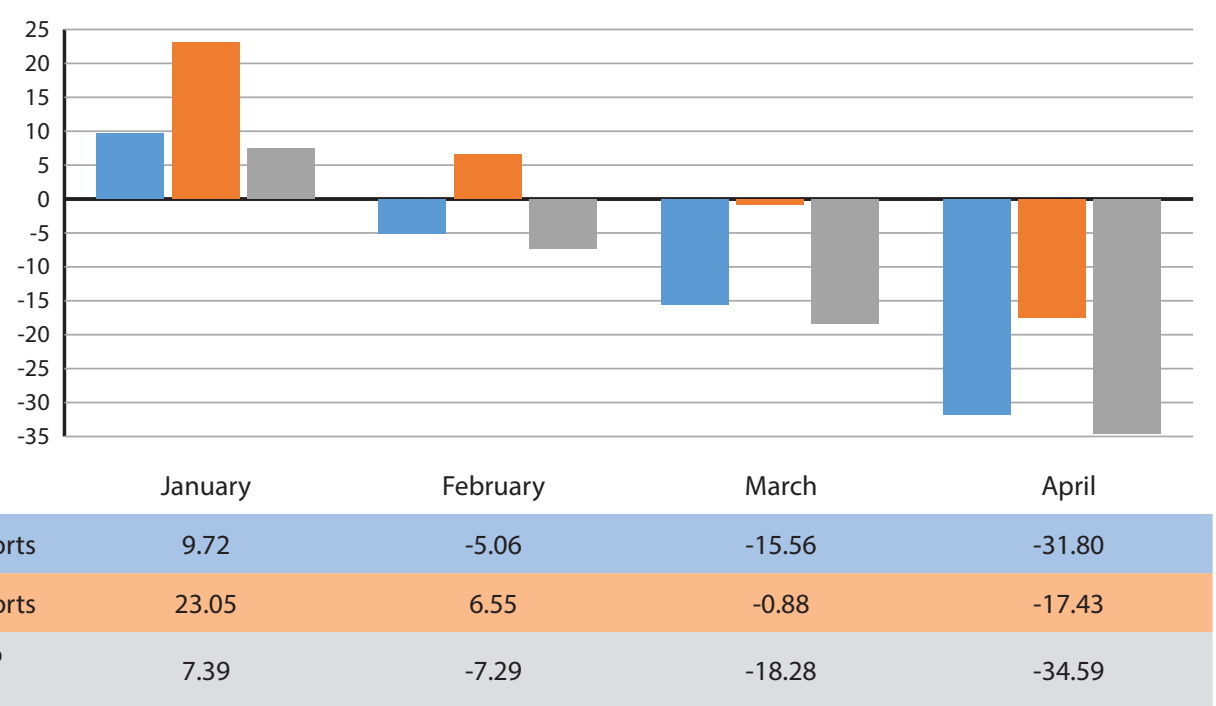

Source: Data from UNCTAD are based on national statistics from 2019 and 2020 . Statistics for April 2020 are preliminary and based on a limited number of countries. 
Figure II: Commodity prices in Africa, from 30 December 2019 to 15 June 2020

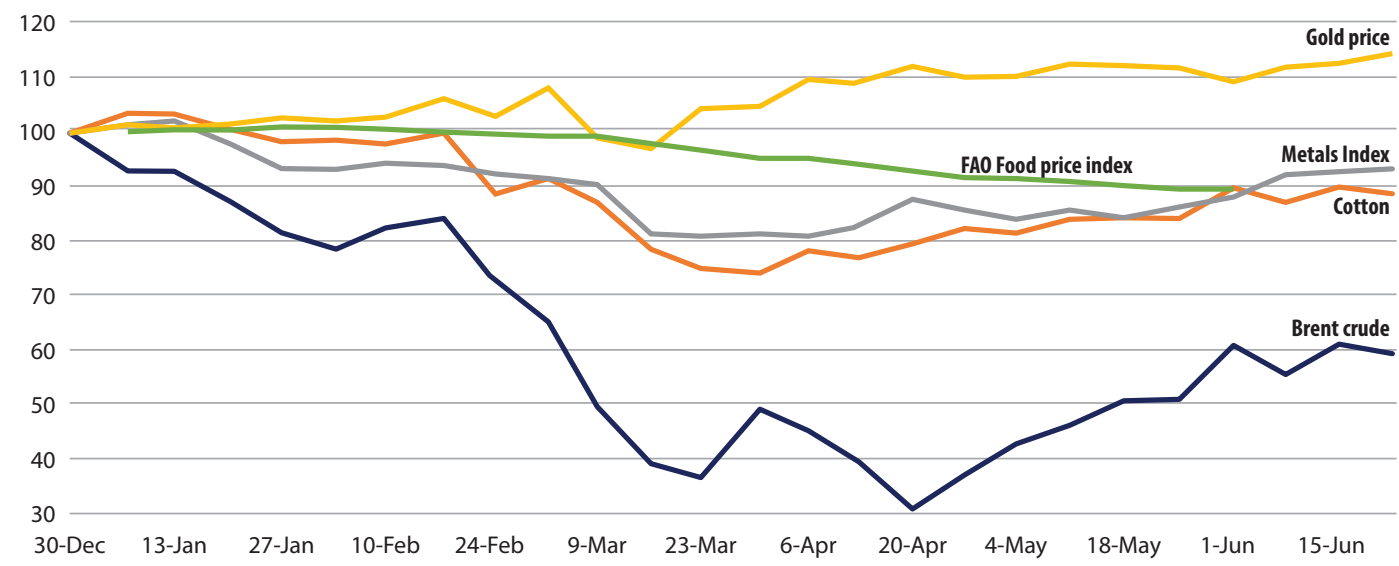

Source: ECA calculations are based on FAO and Trading Economics, June 2020.

Figure III: Africa's imports on a monthly basis (year-on-year percentage changes), 2020 compared to 2019

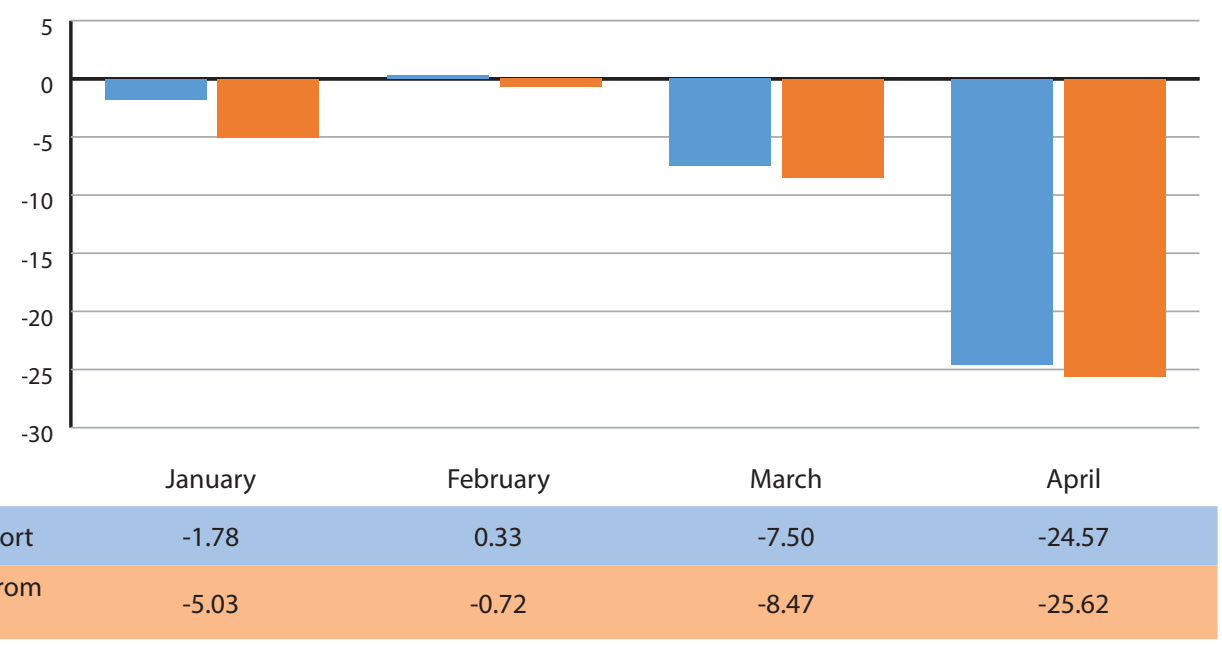

Source: Data from UNCTAD are based on national statistics from 2019 and 2020. Statistics for April 2020 are preliminary and based on a limited number of countries.

The World Health Organization (WHO) has emphasized that restrictions may interrupt needed aid and technical support, may disrupt business and may have negative social and economic effects on the affected countries. With this in mind, it is critical that customs administrations continue to facilitate not only relief goods, but goods in general (WHO, 2020). WHO has further expressed concerns that overly strict official border-crossing bans may increase incentives to cross borders through routes not covered by customs authorities thereby evading health checks, which risks undermining their intended role of protecting public health (IFPRI, 2020). The World Customs Organization (WCO) and the International Road Transport Union has jointly called on customs administrations worldwide (WCO and International Road Transport Union, 2020) to do the following:

» Ensure coordinated cross-border interventions in cooperation with other national border agencies and implement international standards, as appropriate 
» Use the TIR system ${ }^{1}$ and its IT tools, to facilitate secure transport under customs control with limited physical checks and less contact between people at borders

» Designate priority (green) lanes for commercial vehicles to reduce border waiting times and introduce other measures to ensure supply chain continuity

»Avoid closing borders to the international transport of goods, particularly for relief goods and personnel and essential goods

» Avoid unnecessary checking of commercial vehicles at borders.

Most African Governments face a difficult decision: to risk cross-border transmission of COVID-19 or to risk disrupting cross-border supply chains, including those for essential life-saving goods. This report provides a critical assessment of existing border restrictions and regulations, with a view to providing guidance on how to strike an appropriate balance between curbing the longterm spread of the virus and facilitating emergency and essential trade. COVID-19 may remain the "new normal" for some time, and African Governments will need to adapt and innovate in order to facilitate new "safe" ways of conducting cross-border trade. Maintaining trade flows as much as possible during the pandemic will be crucial in providing access to essential food and medical items and in limiting negative impacts on jobs and poverty.

1 The "TIR system" refers to an international system of customs controls that allows goods to transit from a country of origin to a country of destination in sealed load compartments. 


\section{COVID-19 cross-border trade challenges}

Across the continent, there are 107 land borders at which long lines of trucks await clearance. Some trucks will fail to make it across the border and either return home with significant losses or rechannel their trade through less safe unofficial routes. Informal cross-border trade, which typically entails traders crossing the border on foot to sell goods or services on the other side, has been particularly hard hit (Luke, Masila and Sommer, 2020).

Disruptions to cross-border trade present significant challenges for Africa's fight against COVID-19, and risk holding back the continent's progress towards the Sustainable Development Goals set out in the 2030 Agenda for Sustainable Development, and the aspirations identified in Agenda 2063: The Africa We Want, of the African Union.

Inadequate or delayed access to emergency COVID-19 supplies Most African countries or regions have introduced guidelines and rules to prioritize and facilitate a flow across the continent of essential goods, including medicines, fuel and food. Yet, broader border disruptions related to new requirements or disputes have also slowed down the smooth flow of essential supplies. This risks exacerbating the impact of COVID-19 on fragile economies, which are reliant on the timely importation of COVID-19 supplies by road. The establishment of "green lanes" for the super-fast clearance of medical supplies can help.

Increased food insecurity The number of Africans suffering from hunger has declined to 20 per cent, but the impact of COVID-19 has the potential to reverse these gains, through compounding other adverse shocks such as drought and extreme weather. COVID-19 border disruptions impact various stages of food value chains from input supply and production, through to food distribution and consumption. Mitigation measures make it difficult to move food from strategic areas of surplus to deficit regions. This amplifies risks leading to negative impacts on food and nutrition security. For example, according to the Integrated Food Security Phase Classification Technical Manual Version 3.0, in May 2020, the East African region experienced an acute food insecurity phase, which was exacerbated by COVID-19 and desert locust infestations, which have hit food distribution efforts and increased losses (Alliance for a Green Revolution in Africa, 2020).

Escalation of prices along key corridors including cities Cross-border trade provides a lifeline for local communities and urban cities spanning entire corridors. Lower volumes of cross-border trade translate into lower supplies and increased prices, other things being equal. In East Africa, many farmers have been unable to move their produce to border markets, which has cut off a vital source of cross-border trade. Much of the food crossing borders ends up in cities in East Africa, which are now experiencing price hikes. Figure IV shows the broad increase in the prices of maize, a key food staple in East Africa, focusing on cities in the following countries: Burundi (Bujumburu), United Republic of Tanzania (Dar es Salaam), Kenya (Nairobi), Rwanda (Kimironko) and Uganda (Kampala), comparing the month in 2020 with the same month in 2019. For example, in Bujumburu, maize prices increased significantly, by about 33 per cent in 
Figure IV: Maize prices in East Africa, growth rate (percentage changes), 2020 compared to 2019

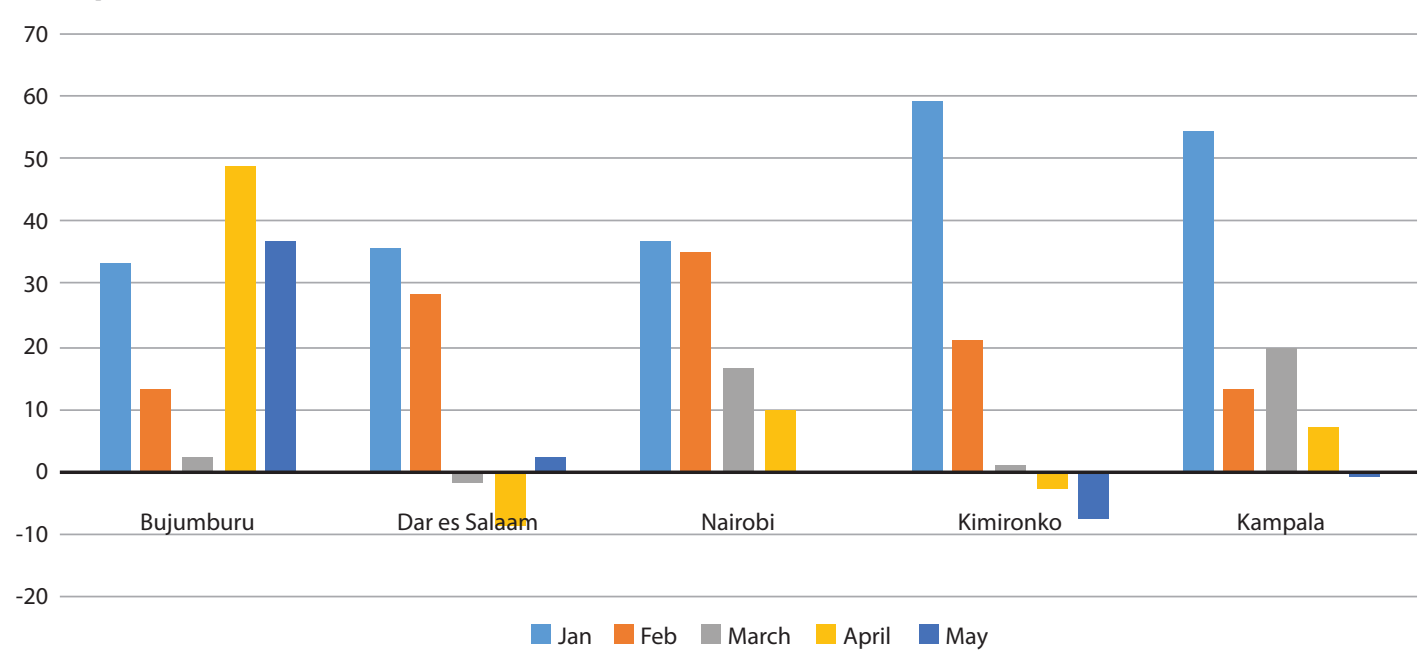

Source: ECA estimates are based on data shared by the Eastern Africa Grain Council for 2019 and 2020.

January 2020, 13 per cent in February 2020, 2 per cent in March 2020, 49 per cent in April 2020 and 37 per cent in May 2020, compared to the same months in 2019. As demonstrated by the 2007-2008 food crisis, food price spikes can spark mass protests. In the current context, such protests would present yet another public health problem.

Loss of income for small-scale cross-border traders Cross-border trade provides an important source of income for cross-border communities, and vulnerable groups, including women and smallholder farmers. Many of these communities live subsistence existences and require weekly trade across the border in order to purchase essentials to survive. The majority of informal cross-border trade consists of perishable agricultural products such as tomatoes, peppers, cassava, fish and eggs. Traders received very short notice - a couple of days in most cases - to prepare for border closures. The result was spoiled stock and hefty losses for the traders. For instance, in Kenya, the cessation of movements in and out of cities was abruptly announced as farmers were en route to markets with truckloads of produce. These farmers were not allowed to pass police barriers and were forced to abandon their harvest of a full season and return home (Luke, Masila and Sommer, 2020). In West Africa, the disruption of informal small-scale cross-border trade activities has reduced effective food demand, due to a loss of incomes resulting from COVID-19 restrictions (Alliance for a Green Revolution in Africa, 2020). This exacerbates issues related to food security.

Increased financial stress Losses of stock and sales from cross-border trade disruptions negatively impact revenue and the ability to repay loans. The risk of financial stress is particularly acute for informal cross-border traders, who are typically unbanked and for bulk stock purchases, rely on expensive informal loan sharks. Many of these traders borrow money early in the morning to acquire merchandise and pay back in the evening of the same day once they have sold their goods. Losses from unsold stock due to COVID-19 home directives and travel restrictions run the risk of quickly escalating into hikes in interest and a spiral of debt (Luke, Masila and Sommer, 2020).

Reversing gains in women's economic empowerment The majority of informal cross-border traders are women. Such trade offers these women an independent source of income, which can further their empowerment in traditionally male-driven households and communities. 
Removing this income source, coupled with increased confinement at home, risks raising the rate of gender-based domestic violence. This concern is being raised by women's rights organizations across the continent.

Slowdown in the development of cross-border value chains COVID-19 has strengthened the case for developing intra-African value chains and unlocking the continent's business potential. At the same time, COVID-19 border disruptions have contributed to blockages in supply chains both within Africa and externally. As African countries transition to a "new normal" under COVID-19, effective and efficient border management will be crucial to provide an environment conducive to the development of resilient African value chains in support of the continent's industrialization and development agendas.

In the light of these challenges, it is crucial that African countries cooperate to harmonize COVID-19 border requirements and regulations in order to reduce delays, while not undermining the safety of trade. Regional economic communities have played a crucial role in coordinating the responses to the pandemic of their member States, with a view to facilitating the free and timely flow of cross-border trade. The following discussion presents a status update on border operations and regulations in four of Africa's regional economic communities, covering 44 African countries, namely, the Common Market for Eastern and Southern Africa (COMESA), the East African Community (EAC), the Economic Community of West African States (ECOWAS) and the Southern African Development Community (SADC). 


\section{Status update: border operations and regulations across regional economic communities}

\section{Community of Eastern and Southern Africa}

To prevent the cross-border contagion of COVID-19, a range of border closures and regulations were introduced across the 21 member States of COMESA. This had the adverse effect of disrupting cargo movements and transit trade across the expansive region. COVID-19 preventive measures, including testing, quarantines and restrictions of gatherings along border points, have made it difficult for cross-border transactions to take place normally. Clearance of cargo has also slowed, leading to long queues hindering supply of essential pharmaceuticals and food items (COMESA, 2020a). The COMESA Business Council coordinated the business community to request the COMESA secretariat to take action to facilitate and ease the movement of essential cargo (Al-Aees, 2020).

On 14 May 2020, Ministers responsible for commerce, trade and industry in the COMESA region agreed on a set of guidelines to facilitate coordination and uniform application of measures across borders, while ensuring public safety and safe trade. The Ministers agreed that the guidelines would be applicable during the COVID-19 pandemic period and will be reviewed as and when necessary (COMESA, 2020d). Given the overlapping membership of COMESA member States with other regional economic communities, the COMESA Guidelines considered similar COVID-19 guidelines developed by EAC and SADC to ensure alignment (see sections below on EAC and SADC).

The COMESA guidelines provide common measures and practices for the movement of goods and services across the region covering a broad range of issues (COMESA, 2020b), including the following:

» Facilitation of cross-border movement of relief and essential supplies

» Transportation of goods and cross-border freight transport operations

» Regulation of air and vessel transportation

» Movement of goods on transit/inland deliveries

»Customs authorities support to the economy

$»$ Sustaining supply chain continuity.

Under those Guidelines, member States are required to publish electronically any newly introduced trade and customs-related measures in response to the pandemic and share the same periodically with the COMESA secretariat. An indicative list of essential goods based on the latest edition of the WCO harmonized system classifications has been published to facilitate clearance of customs and border requirements. In adopting the Guidelines, Ministers 
acknowledged that, despite the incidence of the pandemic, the implementation of the Common Market policies on the movement of goods, services and persons should continue to be governed by the principle of market integration and regional cooperation among the member States.

The Guidelines were published and gazetted on 10 June 2020. This means that member States are now expected to integrate them at the national level as part of the country-based response measures to COVID-19. The ministries responsible for coordinating the implementation of COMESA programmes in member States have been assigned to lead in the application of the Guidelines and ensure their provisions inform decision-making at the national COVID-19 response committees (COMESA, 2020c).

The secretariat has also launched an online platform for exchanging information on the availability of essential products among member States as part of the response measures to the COVID-19 pandemic. This is consistent with the COMESA digital trade facilitation programme, which the organization is encouraging member States to embrace. Implementation of the Guidelines to facilitate the movement of goods and services across the region will be crucial to facilitate the movement of surplus essential supplies to deficit regions, and support the development of competitive regional supply chains in the medium to long term (COMESA, 2020d).

\section{Box 1: COMESA implements emergency measures to support trade facilitation for small-scale cross-border traders during COVID-19}

Since the onset of COVID-19, small-scale traders have been unable to cross borders as they have traditionally done, either to buy or sell goods.

In May 2020, as part of emergency measures to support trade facilitation for small cross-border traders during the time of COVID-19, COMESA dispatched consignments of personal protective equipment (PPEs) to eight border points under the COMESA small-scale cross-border trade initiative. The emergency kit includes over 10,000 face masks, gloves and hand sanitizers. The kit was procured at a cost of $\$ 8,000$ and will help small-scale traders to continue their operations, at the same time protecting Trade Information Desk Officers who help small-scale traders with clearance of goods, mediation when disputes arise, and adherence to policies such as the simplified trade regime (COMESA, 2020a).

In the Democratic Republic of the Congo, Rwanda and Uganda, the Great Lakes Trade Facilitation Project has engaged stakeholders to come up with innovative means of trading across the borders of the three countries. These innovations are targeted at easing the movement of goods and avoiding food shortages. Since cross-border trade by foot has become nearly impossible with the COVID-19 border restrictions, a new concept of bulk-buying has been developed whereby goods are procured in large consignments in collaboration with suppliers across the borders. Led by the Cross-Border Traders' Associations, this concept has helped traders minimize the risk of COVID-19 spread and has allowed safe trade.

Small-scale cross-border trade is conducted by grouping goods from representatives from Cross-Border Traders' Associations, who note down the requirements of their members. This constitutes the consolidated list of orders to be sent to their counterparts on the other side of the border. Prices are discussed and agreed on over the telephone. A truck escort is authorized to accompany the vehicle in order to receive payments with mobile money transactions. Once the goods arrive, the traders share them out and proceed with trading at their different points of sale. This limits the movement of people to the strict minimum. Only the driver conveys the goods accompanied by the group representative, responsible for cash transactions as well distribution of the merchandise among members (COMESA, 2020e).

Source: COMESA (2020a and 2020e) 
Over the previous decade, COMESA has stepped up its support for small-scale cross-border traders, and has served as an African pioneer for the simplified trade regime. This awareness on the importance of extending the benefits of freer trade to informal traders is also reflected in the secretariat's COVID-19 response, highlighted in box 1.

\section{East African Community}

In response to the COVID-19 outbreak, East African countries introduced various lockdown measures and travel restrictions. In order to maintain the supply of essential goods, crossborder ground transportation using trucks was maintained. Yet, since truck drivers serve as a conduit for spreading COVID-19, partner States introduced an array of new measures at borders, which have reportedly disrupted trade and contributed to days-long queues and protests at borders (see figures $\mathrm{V}$ and $\mathrm{VI}$ ).

To overcome these border challenges, several attempts have been made to convene a virtual Heads of State Summit, which did not eventuate because the requisite quorum (in accordance with Rule 11 of the Rules of Procedure) was not attained. The lack of coordination at the political level has exposed the region to wider cross-border spread of the virus. Border testing has uncovered cases involving cross-border truck drivers (Anami, 2020). At some borders, this has contributed to a backlash against truck drivers. For example, the Namanga border in Kenya was classified as a high-risk area by the Government after recording a high number of COVID-19 infections, especially among truck drivers. Many cases have been reported of truck drivers being harassed and attacked following rumours that drivers are transmitting the coronavirus across East Africa (Wasike, 2020).

Progress was achieved on 12 May 2020, when four of the six EAC Heads of State (Kenya, Rwanda, South Sudan and Uganda), held an online meeting to discuss coordination in response to COVID-19. A decision was made to appoint the Ministers responsible for health, transport and

\section{Figure V: Cross-border challenges in East Africa}
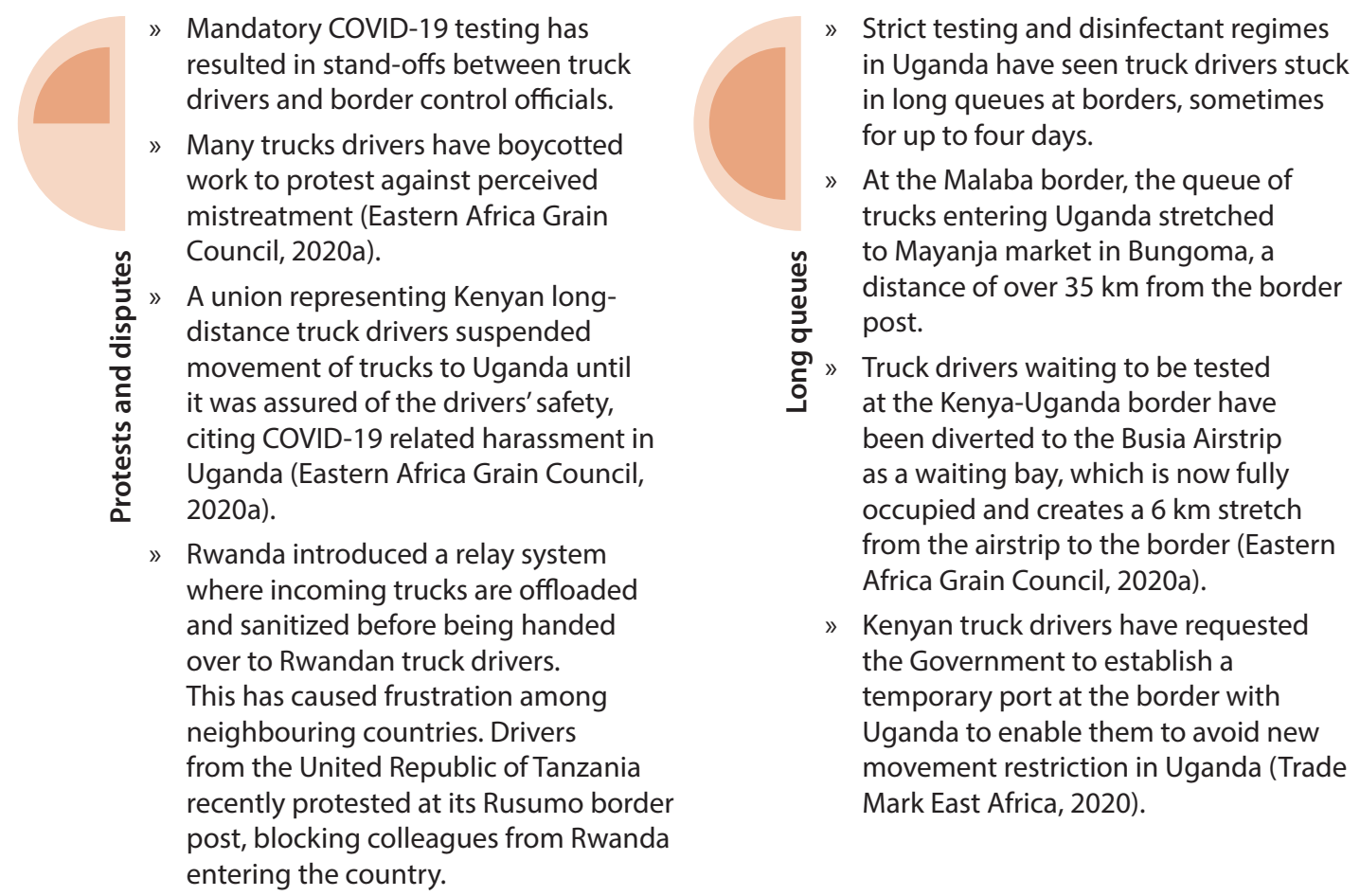

Sources: Eastern Africa Grain Council (2020a and 2020b) and Trade Mark East Africa (2020). 
EAC affairs as focal persons for the region's COVID-19 response plans. Key resolutions relating to facilitating cross-border trade required partner States to:

» Finalize and adopt an EAC digital surveillance and tracking system for drivers and crew on COVID-19 for immediate use

» Develop a regional mechanism for COVID-19 testing certification and monitoring of truck drivers

» Prioritize regional value and supply chains to support local production of essential medical products and supplies including masks, sanitizers, soaps, coveralls, face shields, processed food, and ventilators as part of the efforts to combat COVID-19 in the region

» Facilitate farming activities during the pandemic and post-COVID-19 period, and support agro-processing and value chains as an import substitution measure

» Establish special purpose financing schemes for small and medium-sized enterprises, to cushion them from the negative effects of the COVID-19 pandemic (Bizimungu, 2020)

Amid deadlock in the region, EAC has intensified efforts to coordinate partner States'responses to COVID-19, with a view to facilitating the free and timely flow of cross-border trade. On 24 April 2020, the EAC Ad-Hoc Regional Coordination Committee on COVID-19 Response signed and published the EAC Administrative Guidelines to Facilitate Movement of Goods and Services During the COVID-19 Pandemic (EAC, 2020a). The objectives of the guidelines are to:

1. Complement national measures against the COVID-19 pandemic;

2. Ensure smooth and uninterrupted movement of goods and services during the COVID-19 pandemic;

3. Encourage local production of essential products during the COVID-19 pandemic;

4. Enhance regional awareness on measures instituted against the COVID-19 pandemic;

5. Mitigate the negative impact of COVID-19 on the free movement of goods and services.

Figure Vl: Trucks at the Malaba border in Uganda, 27 May 2020

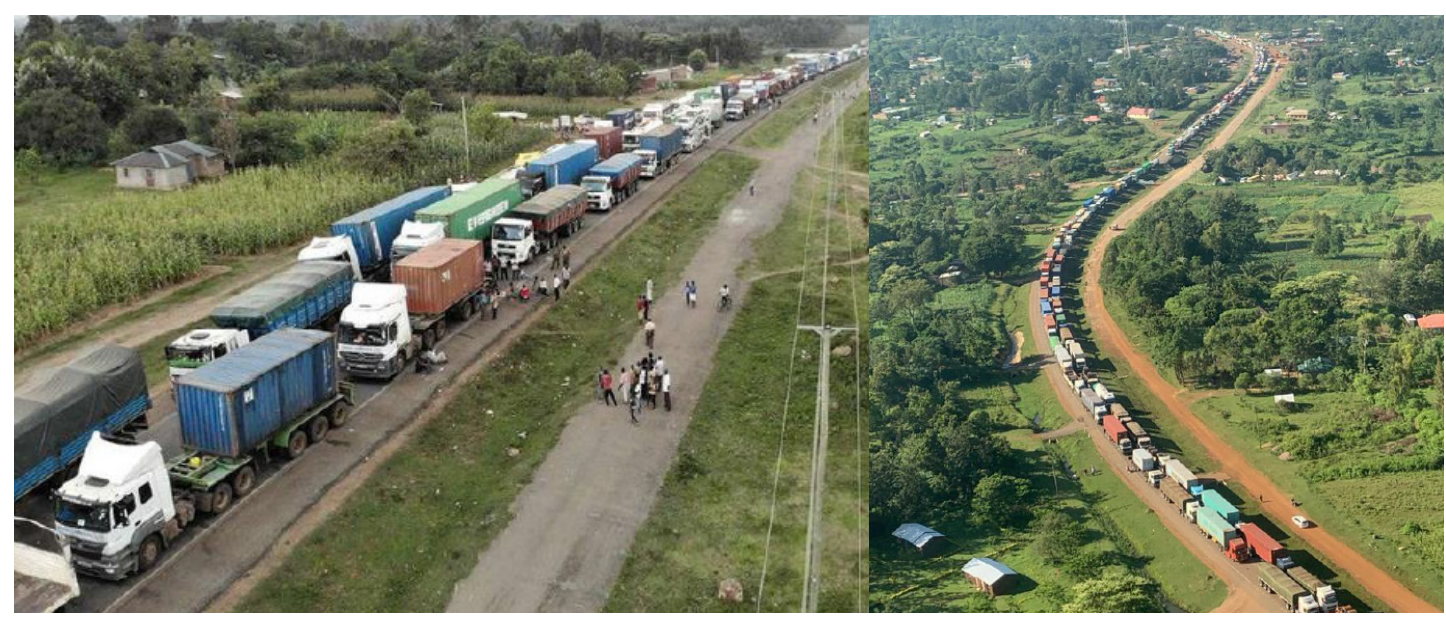

Source: The photographs are published courtesy of the Eastern Africa Grain Council, and were taken from its weekly updates on the COVID-19 pandemic (Eastern Africa Grain Council, 2020a ). 
In these guidelines, the movement of trucks and cargo is classified under essential services. To support the implementation of these guidelines and progress on the resolutions of the Heads of State, EAC has introduced a number of targeted initiatives, many of which have now been officially adopted by partner States.

Distribution of mobile laboratories and test kits The EAC secretariat has deployed mobile laboratories and coronavirus test kits to all EAC partner States, as part of a $\$ 1.8$ million donation by the Mobile Laboratory Project funded by the Government of Germany through KfW ${ }^{2}$. The secretariat committed to distribute vehicles fitted with laboratory and ICT equipment, together with all the necessary consumables of a fully functional laboratory to conduct COVID-19 testing (EAC, 2020b). As of 2 May 2020, nine mobile laboratories had been deployed to partner States (Anami, 2020).

Regional electronic cargo and drivers tracking system On 29 May 2020, EAC partner States adopted the EAC Regional Electronic Cargo and Drivers Tracking System, which is now hosted at EAC headquarters in Arusha, United Republic of Tanzania. The system is designed to share truck driver's information leveraging on that which is managed and operated by revenue authorities in the region, and the existing health information systems in partner States. Truck drivers are required to present themselves for testing before customs and immigration clearance. The Regional Electronic Cargo Tracking System is then used to trace the movement of drivers, so that when the results come in, those who test positive are immediately intercepted and quarantined. The system requires truck drivers to upload an application on their mobile telephones, which allows users to share information across borders in a transparent manner. The digital surveillance tracker interfaces and connects directly to designated laboratories in the partner States (EAC, 2020c).

EAC COVID-19 test certificate On 29 May 2020, partner States adopted the EAC COVID-19 test certificate for truck drivers and crew members, to facilitate a common approach to certifying results of those tested for COVID-19. The COVID-19 certificates generated for drivers and crew members who have undergone tests are shared with all respective stakeholders both at accredited designated testing points and border crossing points in the region. The certificate that is recognized in EAC is valid for 14 days, and allows the owners to travel in the region without being subjected to retesting unless they are found to have signs and symptoms of COVID-19 upon screening at checkpoints using the screening tool. The certificates are issued only for those drivers and crew members who test negative for COVID-19. Those who test positive are expected to follow existing national protocols to access care and other services (EAC, 2020c).

Sensitization and community engagement The EAC secretariat has put in place a Regional Coordination Committee on Riskand Communication and Community Engagement. The Committee has mobilized resources for risk and community engagement to reduce the spread of COVID-19 in the region, and the framework is implemented by partner States and partners, including the International Federation of Red Cross and Red Crescent Societies (IFRC). The secretariat is planning to develop harmonized COVID-19 sensitization material to be disseminated in the region and customized by individual partner States (EAC, 2020b).

$2 \mathrm{KfW}$ is a State-owned German development bank. The name, "KfW", is the abbreviation of its original name: "Kreditanstalt für Weideraufbau" ("Credit Institute for Reconstruction"). 
Capacity building at airports The EAC secretariat is providing capacity building of staff at the eight international airports in the region as part of the support package received from the Government of Germany. The trainings are organized and coordinated by the Civil Aviation Safety and Security Oversight Agency and implemented by the African Medical and Research Federation Flying Doctors. Initial training courses target a total of 240 key airport personnel who are expected to spearhead the development and delivery of targeted training sessions for all other airport personnel (Eastern Africa Grain Council, 2020a). Training and capacity building are also crucial elements covered in the EAC Administrative Guidelines referred to previously.

Although EAC member States remain severely affected by COVID-19 in terms of border disruptions (see box 2), these regional-level guidelines and initiatives are expected to offer a foundation for building greater coordination at the national level. Regional directives have the benefit of embodying regional priorities and not being driven by a single country's national interests. This reduces the likelihood of uncooperative behaviour and disputes. Shorter queues at the borders are already being observed following the introduction of the harmonized EAC COVID-19 test certificate.

\section{Box 2: Kenya Border Operations, as at 5 June 2020}

According to the COVID-19 Supply Chain and Markets Update of 5 June 2020, by the World Food Programme - Kenya Country Office, four of the eight assessed customs border stations reported completely normal operations, namely, Busia (Kenya-Uganda), Lokichoggio (KenyaSouth Sudan), Moyale (Kenya-Ethiopia) and Lunga Lunga (Kenya-United Republic of Tanzania). However, challenges remained at the other four borders, as elaborated below.

Malaba (Kenya-Uganda) Long queues at the border $(80 \mathrm{~km})$ were reported in May 2020. The main cause was commercial truck drivers travelling either without or with an invalid COVID-19 certificate. Kenya is considered a high-risk country, especially by the Ugandan authorities. On 1 June 2020, the Kenyan Ministry of Health sent a taskforce to the Webuye-Malaba highway to collect samples from the queuing truck drivers. The samples are taken to either Moi Teaching Referral Hospital in Eldoret or Kisumu District Hospital; the test results take between 24 and 48 hours to process. This has reduced the length of the queues to less than $40 \mathrm{~km}$. An accelerated lane for truck drivers with a valid COVID-19 certificate has also been created, and the movement of inbound trucks into Kenya has been completely cleared.

Nadapal (Kenya-South Sudan) A new policy from the county government of Turkana was issued stating that all truck drivers, irrespective of ownership of a valid COVID-19 certificate, should be tested. This process takes about three days and has hence created slight delays at the border. The county government is insisting on undertaking their own testing to mitigate against nongenuine certificates.

Namanga (Kenya-United Republic of Tanzania) The District Commissioner in the United Republic of Tanzania in charge of the border shut it from 2 June 2020, citing a high risk of COVID-19 infections from Kenyan drivers. There is no crossing of trucks and queues have developed on both sides of the border.

Lwakhakha (Kenya-Uganda) This is a customs border in Bungoma county that is used as a subsidiary to the Malaba border. It is a satellite border used mainly to facilitate movement of empty trucks to or from Malaba. Lwakhakha is mainly used to decongest traffic flow or as a crisis management facility, and trucks using this border must comply with the strict capacity limit of less than 10 tons per truck. This means normal commercial trucks that are loaded with gross axle weights of 48 tons per vehicle cannot use the road that connects to this border crossing as they would damage it. The road infrastructure is very poor despite the roads being newly tarmacked.

Source: WFP - Kenya Country Office, COVID-19 Supply Chain and Markets Update, 5 June 2020 (2020). 
In order to minimize the risk of cross-border transmission of COVID-19 by truck drivers in EAC, the African Union, IOM, UNICEF and WHO have also prepared a recommended package of infection prevention and control interventions for truck drivers at different stages of their journey (pre-departure, at points of entry, and within the different countries they traverse). The recommendations are based on international best practice on testing, screening, certification, hygiene and the use of personal protective equipment (PPE). This package offers unbiased and technical guidance on how to simultaneously facilitate trade and tackle COVID-19 (African Union, IOM, UNICEF and WHO, 2020).

Furthermore, many trade and development organizations with a presence in East Africa have invested resources in supporting EAC partner States to respond to COVID-19 and facilitate trade. Trade Mark East Africa is working closely with the EAC secretariat to establish a task force to guide joint work in response to COVID-19, including in the following key areas: deepening safe trade protocols, supporting coordinated trade policy responses, driver and corridor tracing, border and trader engagement, airfreight and e-commerce regulation and recovery (Trade Mark East Africa, 2020). The Eastern Africa Grain Council monitors and provides regular reports to its members on the cross-border situation at border crossings in the region. They also provide technical and logistical support to their members to facilitate trade in grains, farm inputs, equipment and services amid COVID-19, and facilitate emergency working capital arrangements with partner financial institutions to ease liquidity constraints (Eastern Africa Grain Council, 2020a ). The World Food Programme (WFP) country offices in East Africa publish weekly COVID-19 updates on supply chains and markets, and are working closely with Governments across the region to support food security efforts (WFP, 2020).

\section{Economic Community of West African States}

ECOWAS member States have imposed varying levels of travel restrictions in response to the COVID-19 pandemic, with many shutting their borders entirely. This has caused significant disruptions to cross-border trade in the region, particularly along major transit routes such as the Cotonou-Niamey, Lomé-Ouagadougou and Abidjan-Lagos corridors.

Many countries in West Africa have suspended all cross-border trade on foot, but allow large freight trucks to cross the border after curfew. Fresh produce, meat and other perishable products are typically transported at night owing to the daytime heat. Curfews nevertheless make the practice impossible (on foot or in a vehicle) and have contributed to significant waste. Many countries have also mandated strict health checks without adding necessary personal, which has contributed to a steep increase in the time taken to deliver goods. Reports indicate that bribe collections along West African corridors have increased by 30 per cent since COVID-19, owing to the general slowdown in road transport, which has facilitated an increase in the incidence of extortion (IFPRI, 2020).

In the light of disruptions to cross-border trade, on 23 April 2020, ECOWAS Heads of State agreed to coordinate measures across the region in an effort to stop the spread of the pandemic and facilitate the free movement of goods and persons. To ensure high-level coordination of regional efforts to contain COVID-19, the Summit appointed the President of Nigeria as the ECOWAS Champion President of the COVID-19 response and eradication process.

Similar to other regional economic communities, ECOWAS prepared a set of guidelines for harmonized facilitation of cross -border trade and transport amid COVID-19. The guidelines 


\section{Box 3: COVID-19 border closure between Ghana and Togo}

On 21 March 2020, Ghanaian and Togolese authorities closed borders between the two countries. The closure was targeted at curtailing all movement of persons across borders, including smallscale traders. Large trucks and vehicles used for the transport of bulky consignments are allowed to cross the border after curfew ( 8 p.m. to 6 a.m.), on the condition that they follow strict hygiene measures.

According to sources at the border, since COVID-19, there has been an increasing trend of smallscale traders joining forces, aggregating their goods, and paying a bundle of fees to truck drivers for transportation and clearance. For this reason, prices of key staples such as rice, tomatoes and peppers have jumped by about 50 per cent in local border towns in Ghana. Branded supermarkets are not an option in these towns, which is why they rely heavily on agricultural produce from Togo.

\section{Aflao-Kodjoviakope border closure in West Africa}

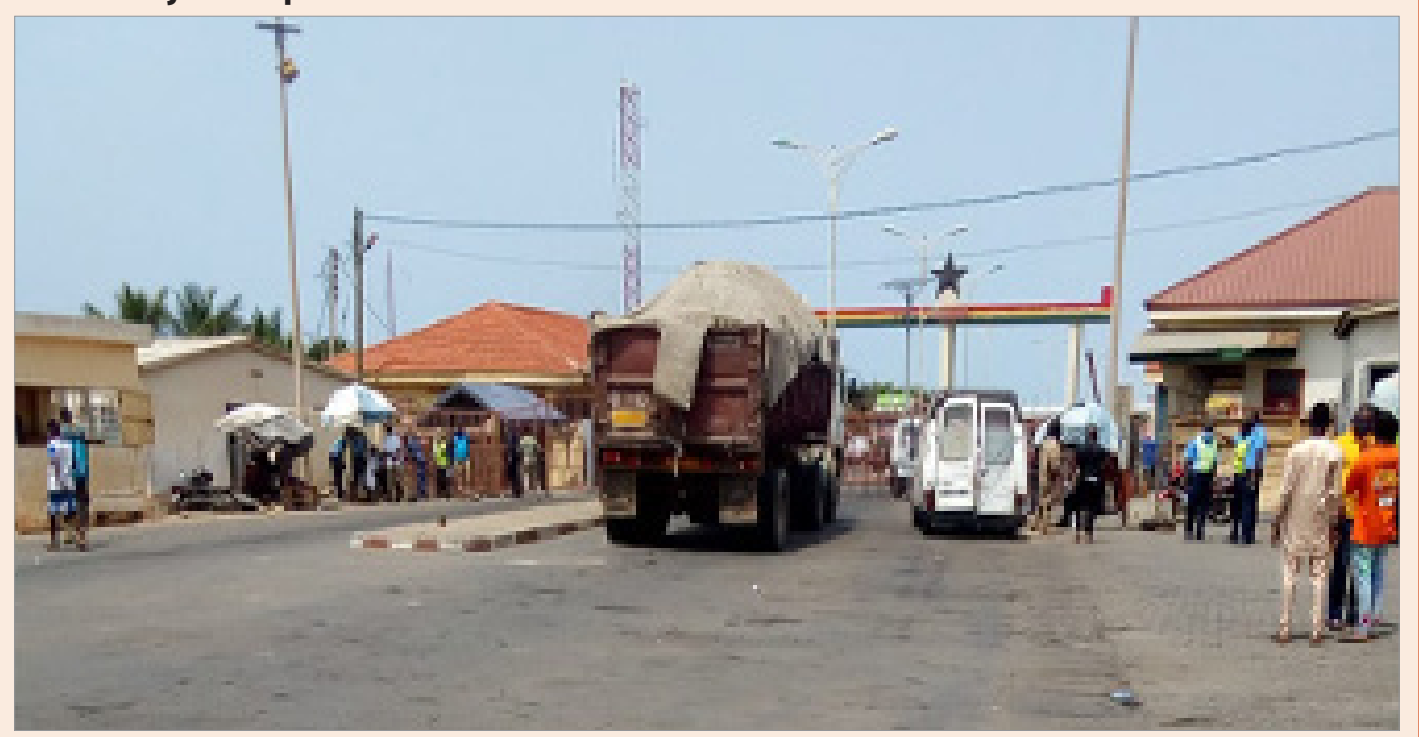

Photo source: The photograph was taken by the ECA enumerator on 18 April 2020.

Source: Luke, Masila and Sommer (2020).

were reviewed by the ECOWAS Ministerial Coordinating Committee on Transport, Logistics and Trade on 17 June 2020 and are expected to be presented for adoption by ECOWAS Heads of State. The objectives of the guidelines (ECOWAS, in press) are to:

1. Define immediate measures to ensure the seamless supply of medical equipment, essential goods and personnel in the fight against the COVID-19 pandemic among ECOWAS member States;

2. Facilitate the coordinated implementation of transport related national COVID-19 measures in cross-border transportation;

3. Ensure the harmonization of operational guidelines for the reopening of air, land and sea borders in line with international industry best practices in regard to restoring user confidence while preventing the spread of COVID-19 across borders.

The guidelines target the reopening of cross-border trade as opposed to only the facilitation of cross-border trade. This reflects the severity and strictness of border closures within the region, which has resulted in the abrupt halt in the trade of many goods and services, including essential items, and a significant slowdown in economic activity. On 17 June 2020, 
the Ministerial Coordinating Committee also recommended the harmonized and gradual reopening of land, air and sea borders for restoring cross-border economic activities, especially for the movement of humanitarian personnel, medical supplies and equipment and essential goods. This reopening hinges on the implementation of the proposed guidelines for crossborder trade, and complementary regional guidelines for the mitigation of health risks. The recommendation is to be submitted to ECOWAS Heads of State, along with the guidelines.

The Ministers have advised on a three-phased approach to the opening of land and air borders, beginning with local internal domestic air and land transport within ECOWAS member States. The second phase involves the opening of land and air borders between ECOWAS member States, to allow the free movement of goods and persons on the basis of strict application of the proposed guidelines for the harmonization and facilitation of cross-border trade and transport in the ECOWAS region. Following a review of the evolution of the COVID-19 pandemic in respective member States, a third phase will be pursued of opening air and land borders to other countries with low and controlled levels (according to WHO classifications) of COVID-19 contamination rates (ECOWAS, 2020a).

The ECOWAS Ministerial Coordination Committee has further called for:

» Accurate information sharing on opening-up measures among member States

» Rapid deployment of the new ECOWAS Interconnected Goods and Transit Management Systems to facilitate speedy and safe clearance of transit goods

» Sharing of information on ECOWAS COVID-19 guidelines and regulations to the private sector, including shipping lines, airlines, cross-border transporters and traders

» Strong collaboration at borders among customs and immigration agencies

» An effective coordination mechanism to follow up on implementation of the guidelines, utilizing existing State or regional structures and committees responsible for ensuring the proper application of free movement protocols.

\section{Southern African Development Community}

Southern African countries have introduced various lockdown measures and travel restrictions to fight COVID-19. Border posts have put in place stringent measures to contain the spread of the virus and customs administrations have activated risk management systems. Most processes have been moved online to reduce direct contact and exposure to the virus, and the physical examination of goods has been suspended.

More than 80 per cent of imported and exported goods in the SADC region are transported through the road network. COVID-19-related lockdowns in member States and the associated public health measures have resulted in significant delays in the movement of vehicles and subsequently in the delivery of essential medical and food supplies to the point of use. The severe lockdown and border measures in South Africa, the largest supplier within SADC, has dealt a significant blow to smaller landlocked import-dependent countries in the region.

These border delays are expected to have detrimental impacts on the food security of vulnerable households. According to the most recent SADC Quarterly Regional Food Security Update, it is 


\section{Box 4: Border disruptions in Zambia}

Zambia has imposed a mandatory quarantine requirement for truck drivers at Livingstone border post. Transit truck drivers complain that to get to Livingstone border post they are screened at least twice in South Africa and Zimbabwe or Namibia, hence there is no need to detain them at Livingstone. The border post reportedly has no ablution facilities, and trucks carrying highly inflammable substances cannot park at an appropriate distance from others.

At Chirundu one-stop border post, Zambian procedures have created significant congestion. On 2 April 2020, there was a queue on the Zimbabwe side of the border of around $9 \mathrm{~km}$. On average, drivers sleep in their trucks two nights in a row with no access to toilets.

\section{Truck drivers stuck at Livingstone border post on 30 March 2020}

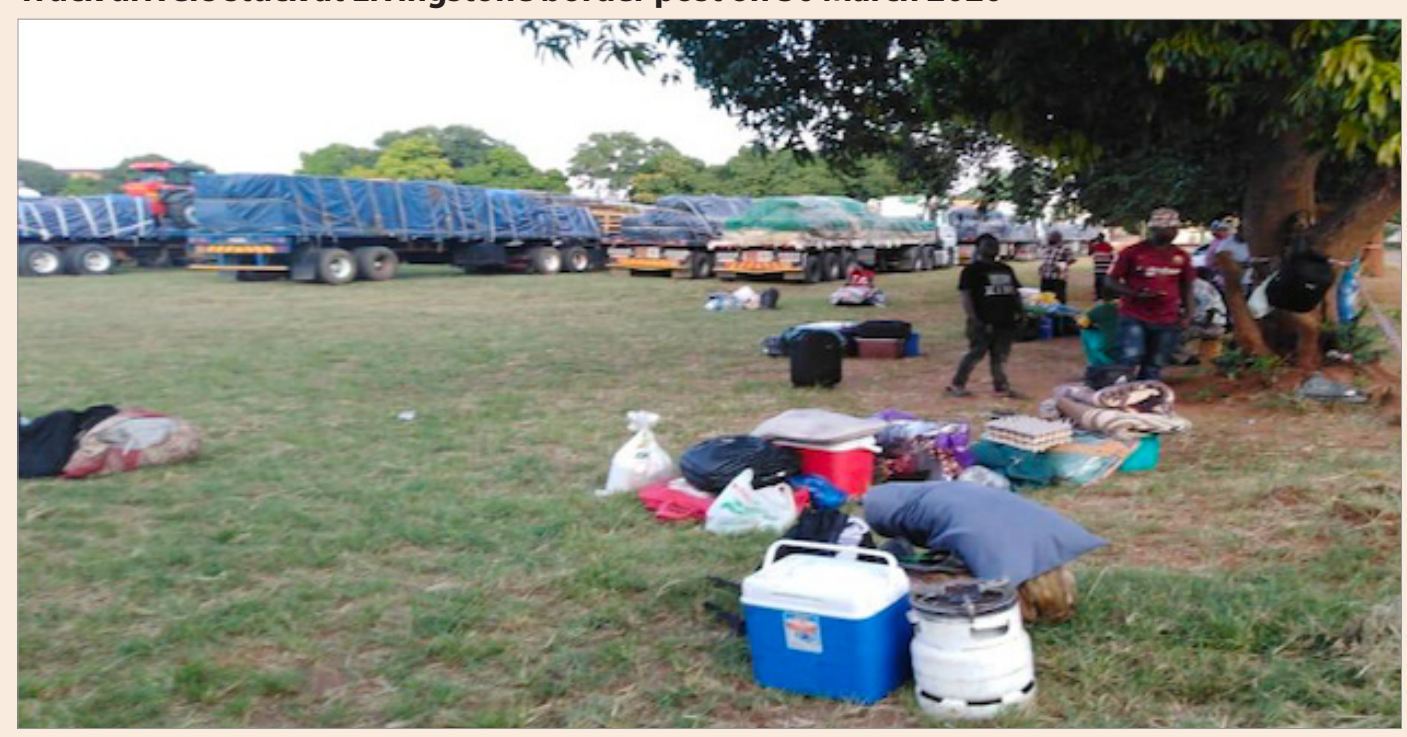

Photo source: The photograph is published courtesy of the Federation of Clearing and Forwarding Associations of Southern Africa, Members Forum (Thsuma, 2020)

Source: Thsuma (2020).

likely that COVID-19 will have a major impact on food and nutrition security and livelihoods in SADC, where about 43 million people are estimated to be acutely food insecure. Despite the region having enough exportable cereal stocks (mainly South Africa), restrictions instituted to control the spread of the coronavirus have reduced access to food, through creating blockages in cross-border food supply chains (SADC, 2020b).

Coordinated border management between some countries (including Botswana, Mozambique, Namibia and South Africa) has helped to ease border disruptions in parts of the region. For example, collaboration between South African and Zimbabwean authorities at Beitbridge border post has facilitated a smooth flow of trucks. At Machipanda-Forbes border post, Mozambican customs officers initially panicked and briefly stopped countries entering their country, but the issue was resolved within hours with the intervention of senior officials. Trucks now move into and out of Mozambique, although the pace is slower than usual due to the screening of drivers by border authorities (Thsuma, 2020).

The overall slowdown in cross-border trade and inconsistent border responses have spurred efforts to align processes and procedures in the SADC region. On 6 April 2020, the SADC Council of Ministers adopted regional guidelines for harmonizing and facilitating the movement of critical goods and services across the region during the COVID-19 pandemic. Similar to the 


\section{Box 5: Trade at unofficial crossings spikes as Zimbabwe confronts food} insecurity

Following the onset of COVID-19, the South African Department of Public Works and Infrastructure made the decision to repair and replace a $40 \mathrm{~km}$ fence at the South Africa-Zimbabwe Beitbridge border crossing. According to the Department of Public Works and Infrastructure, the objective was to prevent "illegal" crossings that could worsen the spread of COVID-19. The repairs were completed on 20 April 2020 and on 27 April 2020, the South African Department of Defence was instructed to intensify patrols along the border fence (Slater, 2020).

Yet, as the COVID-19 pandemic unfolds, food insecurity has become a serious problem in Zimbabwe. Despite the newly repaired border fence, thousands of people are reportedly illegally crossing the Beitbridge border daily to purchase foodstuffs in the nearby town of Musina, Limpopo. South African drivers without work due to the COVID-19 lockdown have started transporting goods from Musina to Zimbabweans waiting at the border. The food products moved across the border include mealie meal, sugar and chicken (Bosch, 2020).

Unofficial border crossings are growing in number due to significant congestion and delays at official border crossings. According to reports from truck drivers using the Beitbridge border post, queues of trucks awaiting clearance can stretch to almost $10 \mathrm{~km}$ into South Africa Beitbridge and it can take five-days to get through. Before lockdown, it reportedly took two hours for to make the crossing into Zimbabwe from South Africa; now it takes almost a week (Chiguvare, 2020).

guidelines developed by other regional economic communities, the SADC guidelines (SADC, 2020d and 2020f) are aimed at the following:

1. Limiting the spread of COVID-19 through transport across borders;

2. Facilitating the implementation of transport-related national COVID-19 measures in cross-border transportation;

3. Facilitating flow of essential goods such as fuel, food and medicines;

4. Limiting unnecessary mass movement of passengers across borders;

5. Harmonizing and coordinating transport-related national COVID-19 policies, regulations and response measures.

The guidelines call for the simplification and automation of trade and transport facilitation processes and documents, and information sharing, and provide guidance on the services to be provided by Governments, transport operators and transport operators associations during the COVID-19 pandemic. Member States are required to establish or assign a national transport and trade facilitation committee or structures with similar mandates. The responsibility of such a committee is to coordinate the implementation of the guidelines and, in particular, to facilitate the resolution of operational issues at borders or roadblocks during the COVID-19 pandemic (SADC, 2020e).

The SADC secretariat has also operationalized a regional COVID-19 trade and transport facilitation cell in order to assist member States with the coordination of cooperation in implementing trade- and transport-related measures during the COVID19 pandemic (SADC, 2020e). This regional body has assembled a collection of COVID-19-related national transport laws and regulations from 11 member States, and begun to analyse them for consistency with the regional guidelines. The analysis indicated that there was a number of non-tariff barriers or disruptions to cross-border trade, including: 
» Strict quarantine requirements A Policy on mandatory quarantine in Zambia of all incoming drivers and vehicles including drivers ferrying essential and perishable cargo

»Police escort fees High fees being charged for police escorts in some member States has caused frustration among operators and drivers

» Commercial truck driver visas The suspension by Mozambique of the issuance of visas to commercial truck drivers is negatively affecting member States who use the port of Beira

» Blocking of foreign trucks Cross-border transport drivers in Malawi have gone on strike, demanding to be supplied with PPE and payment of a COVID-19 risk allowance. Striking drivers have threatened to block foreign trucks from entering Malawi until their demands are met.

More broadly, the analysis revealed that there are differences in the ways that member States are implementing trade and transportation laws and regulations during the COVID-19 emergency. Congestion at border posts is still significant due to a lack of harmonization of public health measures at borders, such as testing and quarantine policies. Despite these challenges, some good practices are emerging, which are summarized in box 6 (SADC, 2020a). Similar to the case of EAC, this highlights the inconsistent implementation of COVID-19 trade and transport guidelines, and points to the need for greater alignment and improved cooperation between border authorities.

On 29 May 2020, the SADC Council of Ministers directed the secretariat to (a) expedite the development of a regional electronic tracking and monitoring system to support the implementation of the standard operating procedures; $(b)$ coordinate with COMESA and EAC in the context of the tripartite arrangement, and the African Union Commission to align and harmonize guidelines to facilitate trade during the COVID-19 pandemic; and (c) establish an online platform that will allow easy access to information regarding the production and trade of medical equipment and supplies (SADC, 2020a).

\section{Box 6: Good practices in cross-border trade in the SADC region}

Botswana and Zambia: Cooperated to clear traffic that had built up at Kazungula during the first week that member States implemented national COVID-19 measures, by joint clearance and collaboration between border agencies and the use of the temporary construction bridge.

Democratic Republic of the Congo and Zambia: Collaborated in clearing traffic that had built up at Kasumbalesa, including by simulating operational modalities for a one-stop border post, which allow officials to operate jointly from one another's territory, and opening an additional road connection between two borders.

Zimbabwe: Designated and published a map of truck stops and garages that could be used by trucks during COVID-19.

Namibia: A public-private partnership constructed a temporary quarantine facility for trucks in Walvis Bay. The facility is fully equipped with COVID-19 hygiene requirements, resting and ablution facilities, and is secured by the police who protect drivers, cargo and vehicles.

Angola: Simplified and waived requirements for submission of stamped original hard copies of documentation and switched to accepting electronic submissions.

Source: SADC Regional Response to COVID-19 Pandemic, Bulletin No.6 (SADC, 2020a) 
On 23 June 2020, the SADC secretariat published Revised Guidelines and Regional Standard Operating Procedures (SOPS) for Management and Monitoring of Cross Border Road Transport at Designated Points of Entry and COVID-19 Checkpoint. That publication includes recommended testing protocol, mutual recognition of test results and a recommended test validity period. The proposals closely mirror the EAC COVID-19 test certificate (SADC, 2020c). Under the revised guidelines, the principle has been removed that limited the facilitation of movement of goods and services across the region during the COVID-19 period to only those termed essential. The revision means that all goods, cargo and services are allowed to flow between member States, while public health measures are observed on safe trade, but priority is given to essential products (SADC, 2020d). This is a step towards fully reopening cross-border trading, and is based on the understanding that COVID-19 is here to stay for a while, and all products that move across borders create business and growth, and help to improve the lives of people within the region (Poverello, 2020). 


\section{A comparison across regional economic communities of COVID-19 guidelines for the movement of goods and services}

As African countries get ready to embark on the implementation of the Agreement Establishing the African Continental Free Trade Area, it is imperative that the regional economic communities harmonize and coordinate the implementation of trade- and transport-related COVID-19 guidelines. Many regional economic communities have overlapping membership, but have agreed to share trade facilitation goals under the Agreement. Table 2 provides a comparison of the existing guidelines of regional economic communities to facilitate the movement of goods and services across borders, and demonstrates that a significant degree of alignment already exists.

The SADC guidelines were the first to be adopted on 6 April 2020. The EAC guidelines were signed and published by the EAC Regional Coordination Committee on COVID-19 Response on 24 April 2020, but have not been officially adopted by member States. Both the EAC and SADC guidelines provided important benchmarks for the drafting of the SADC guidelines, which were adopted on 14 May 2020. ECOWAS guidelines were adopted by the Ministerial Coordinating Committee more recently, on 17 June 2020, and are scheduled to be presented to the Summit for adoption at the Heads of State level shortly. The phased timelines of introducing the guidelines across the regional economic communities, has enabled a process of learning and alignment across regional groupings.

Guidelines have also been aligned to regional and international best practice, including COVID-19 related guidelines prepared by the African Union Commission, African Civil Aviation Council, International Civil Aviation Organization (ICAO), International Maritime Organization (IMO), International Organization for Migration (IOM), WCO, WHO and World Trade Organization (WTO).

Facilitating the cross-border movement of essential COVID-19 goods and services are prioritized within the scope of the guidelines of all regional economic communities. This typically includes land, port and air transport, including transit trade. The guidelines emphasize the importance of facilitating trade under a "safe" environment, including screening, testing, and appropriate sanitary, quarantine and social distance procedures and facilities. Most guidelines encourage the use of digital means to support the transition to safe trade. The importance of disseminating information on the topics covered by the guidelines and supporting capacity building to comply with new COVID-19 regulations are included in all guidelines of the regional economic communities, although to a differing degree and using a variety of approaches. Monitoring and evaluation are also included as a central component in all the guidelines, reflecting the need for continual tracking of progress in implementation. SADC guidelines go one step further and require the establishment of a regional transport and trade facilitation cell to assist and coordinate member States and corridor groups in implementing the provisions of the 
Table 2: Comparison across regional economic communities of guidelines to facilitate the movement of goods and services

\begin{tabular}{|c|c|c|c|}
\hline & Date of introduction & Scope & Alignment \\
\hline COMESA & $\begin{array}{l}\text { 14 May 2020: } \\
\text { Adopted by the } \\
\text { eighth meeting of } \\
\text { the Extra-ordinary } \\
\text { Council of Ministers } \\
\text { - } 10 \text { June 2020: } \\
\text { Published and } \\
\text { gazetted }\end{array}$ & $\begin{array}{l}\text { - Facilitating cross-border movement of } \\
\text { relief and essential supplies } \\
\text { - Transport of goods and cross-border } \\
\text { - Creight transport operations } \\
\text { - Cross-border road passenger transport } \\
\text { - Air transport } \\
\text { - Other modes of cross-border transport } \\
\text { - Regulating and controlling trucks, aircraft } \\
\text { and vessels carrying essential goods and } \\
\text { - } \text { services } \\
\text { - Mandling of cargo at ports of entry } \\
\text { - deliveries } \\
\text { - Customs authorities support to the } \\
\text { economy and sustaining of supply chain } \\
\text { continuity } \\
\text { - Trade in services } \\
\text { Monitoring and evaluation }\end{array}$ & $\begin{array}{l}\text { Aligned to COVID-19 } \\
\text { guidelines of the } \\
\text { African Union, EAC, } \\
\text { SADC, WCO and WHO }\end{array}$ \\
\hline EAC & $\begin{array}{l}\text { 24 April 2020: } \\
\text { Signed and } \\
\text { published by } \\
\text { the EAC Ad- } \\
\text { Hoc Regional } \\
\text { Coordination } \\
\text { Committee on } \\
\text { COVID-19 Response } \\
\text { - Not officially } \\
\text { adopted by member } \\
\text { States }\end{array}$ & $\begin{array}{l}\text { - Trade facilitation } \\
\text { - Gazetted transit routes } \\
\text { - Handling of cargo at ports of entry/ } \\
\text { internal borders } \\
\text { - Movement of goods in transit/inland } \\
\text { deliveries } \\
\text { - Priority treatment for cargo mitigating } \\
\text { the COVID-19 pandemic } \\
\text { - Payments and communication services } \\
\text { - Application of customs laws and } \\
\text { - Interpretation } \\
\text { - Inspection of goods for quality and safety } \\
\text { - Training and capacity building } \\
\text { - Monitoring and evaluation }\end{array}$ & $\begin{array}{l}\text { Aligned to the } \\
\text { COVID- } 19 \text { guidelines } \\
\text { of WCO and WHO }\end{array}$ \\
\hline ECOWAS & $\begin{array}{l}\text {-17 June 2020: } \\
\text { Guidelines were } \\
\text { adopted by } \\
\text { ECOWAS Ministerial } \\
\text { Coordinating } \\
\text { Committee } \\
\text { - Scheduled to be } \\
\text { presented to the } \\
\text { Summit of the } \\
\text { ECOWAS Authority } \\
\text { of Heads of State } \\
\text { and Government for } \\
\text { adoption }\end{array}$ & $\begin{array}{l}\text { - Protection for transport sector workers } \\
\text { and passengers } \\
\text { - Air transport } \\
\text { - Cross-border land transport and free } \\
\text { movement of persons } \\
\text { - } \text { Border formalities } \\
\text { - Operation of seaports } \\
\text { - Trade facilitation of COVID-19 goods and } \\
\text { - } \text { services } \\
\text { - Genocacy and information sharing } \\
\text { - Monitoring and evaluation }\end{array}$ & $\begin{array}{l}\text { Aligned to the } \\
\text { COVID-19 guidelines } \\
\text { of WHO, WCO, } \\
\text { WTO, IOM, IMO, } \\
\text { ICAO, African Union } \\
\text { Commission, Africa } \\
\text { Civil Aviation Council, } \\
\text { IATA, UNCTAD and IRO }\end{array}$ \\
\hline SADC & $\begin{array}{l}\text { - } 6 \text { April 2020: } \\
\text { Adopted by Council } \\
\text { of Ministers } \\
\text { - Revised guidelines } \\
\text { were published on } \\
23 \text { June } 2020\end{array}$ & $\begin{array}{l}\text { - Cross-border freight transport operations } \\
\text { (all goods and services) } \\
\text { - Cross-border road passenger transport } \\
\text { - Regulation of other modes of cross- } \\
\text { border transport } \\
\text { - Services and facilities to be provided } \\
\text { - Regulating and controlling trucks } \\
\text { carrying essential goods and services } \\
\text { - Monitoring and evaluation }\end{array}$ & $\begin{array}{l}\text { Assume member } \\
\text { States are } \\
\text { implementing policies } \\
\text { and measures to } \\
\text { combat COVID-19 } \\
\text { recommended by } \\
\text { WHO, WCO, ICAO and } \\
\text { IMO }\end{array}$ \\
\hline
\end{tabular}

Source: COMESA (2020), EAC (2020), ECOWAS (in press), SADC (2020d and 2020f). 
guidelines during COVID-19. ECOWAS guidelines are the only guidelines to include a dedicated section on gender considerations.

Some regional economic communities and their member States have advanced further in certain areas of COVID-19 trade facilitation, and have introduced practical measures and interventions to complement implementation of existing guidelines. This comparative section identifies a set of best-practice interventions to facilitate safe trade during the pandemic, drawing upon the experiences of the four regional economic communities analysed in this report (table 3). Coordinated implementation of these best practices across the continent would help to contain cross-border spread of the virus, while reducing the costs and increasing the efficiency of cross-border trade.

\section{Table 3: Best-practice COVID-19 border regulations and interventions across the regional economic communities}

\begin{tabular}{|c|c|}
\hline Health screening & $\begin{array}{l}\text { - Conduct mandatory, thorough health screening of all incoming and outgoing truck } \\
\text { drivers and crew } \\
\text { - Coordinate health screening when there is a functioning one-stop border post } \\
\text { - Ensure that all border points are reinforced with requisite personnel to carry out } \\
\text { health screening and COVID-19 testing }\end{array}$ \\
\hline $\begin{array}{l}\text { Testing and } \\
\text { certification }\end{array}$ & $\begin{array}{l}\text { - Deploy mobile laboratories and test kits to all border posts } \\
\text { - Test all drivers and crew before the commencement of their trip } \\
\text { - Immediately isolate persons who exhibit symptoms or test positive for COVID-19, in } \\
\text { - Expedite the movement and clearance of persons with a valid negative COVID-19 } \\
\text { certificate } \\
\text { - Develop a regional harmonized test certificate that is valid for a period of } 14 \text { days, } \\
\text { and allows the owner to travel within the region without being subjected to } \\
\text { retesting unless he or she is found to have COVID-19 symptoms on screening at } \\
\text { checkpoints using the screening tool } \\
\text { - Share COVID-19 certificates generated for drivers and crew members who have } \\
\text { undergone tests with all respective stakeholders both at accredited designated } \\
\text { testing points and border crossing points in the region }\end{array}$ \\
\hline Hygie & $\begin{array}{l}\text { - Provide hygiene facilities at all border posts } \\
\text { - Provide PPE and other medical supplies and equipment for frontline personnel at } \\
\text { border crossings and checkpoints, including public health, immigration, customs, } \\
\text { law enforcement and other border agencies } \\
\text { - Enforce mandatory requirement for drivers and crew to wear masks and use } \\
\text { sanitized products during their trip } \\
\text { - Provide facilities to disinfect cargo and trucks }\end{array}$ \\
\hline Crew size & $\begin{array}{l}\text { - Introduce regulation so that vehicles can only travel with one driver and an } \\
\text { appropriate number of crew members in line with social distancing directives (e.g. } 2 \\
\text { or } 3 \text { crew members) }\end{array}$ \\
\hline $\begin{array}{l}\text { Border } \\
\text { management and } \\
\text { cooperation }\end{array}$ & $\begin{array}{l}\text { - Adopt the latest edition of the WCO harmonized system classification reference for } \\
\text { COVID-19 medical supplies to facilitate essential trade } \\
\text { - Use risk management practices and strategies and perform inspections on essential } \\
\text { food and medical supplies and relief goods only if deemed high risk } \\
\text { - Introduce or enhance pre-clearance of goods and encourage coordination of } \\
\text { inspections and single-window processing } \\
\text { - Ensure that border controls are organized in a way that prevents the risk of } \\
\text { dangerous overcrowding } \\
\text { - Designate priority lanes for essential goods or for those truck drivers with a valid } \\
\text { - negative COVID-19 test certificate } \\
\text { - in transit } \\
\text { - Scale up border patrols in order to deter people who might attempt to cross borders } \\
\text { at unauthorized or ungazetted crossings }\end{array}$ \\
\hline
\end{tabular}




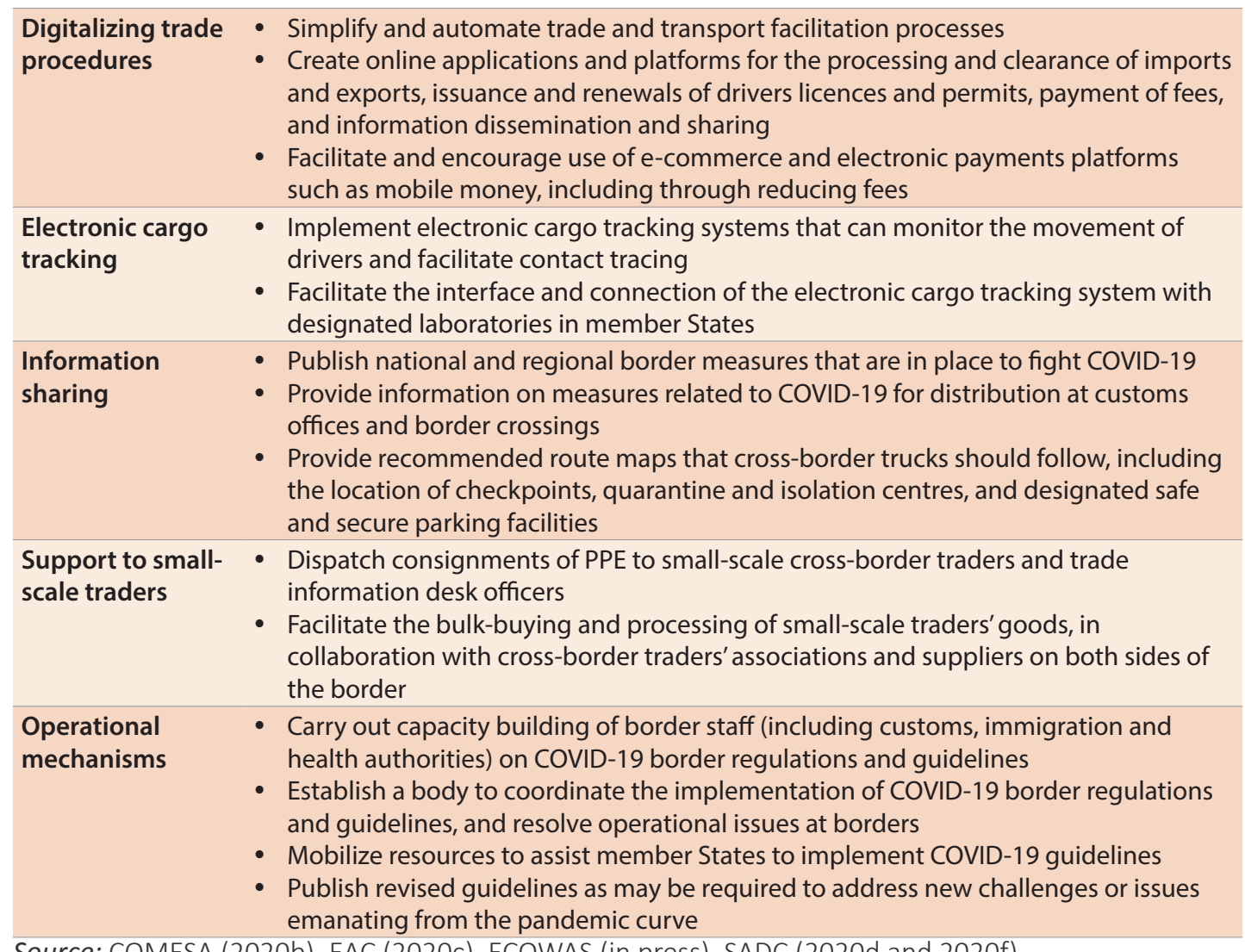

Source: COMESA (2020b), EAC (2020c), ECOWAS (in press), SADC (2020d and 2020f).

\section{COVID-19: an opportunity to overcome long-standing cross-border trade challenges}

Cross-border trade challenges are not new to Africa. Trade and customs facilitation present longstanding obstacles to boosting intra-African trade in goods and services. Studies show that, on average, the costs of transportation in African countries are 63 per cent higher compared to the average in developed economies and 135 per cent higher than in Europe. The average cost of freight as a percentage of total value of imports is around 11.4 per cent for Africa compared to 6.8 per cent for developed countries (African Export-Import Bank, 2020). According to AUDANEPAD, the average customs transaction in Africa involves between 20 and 30 different parties, 40 documents, 200 data elements, and the rekeying of 60-70 per cent of all data at least once. The typical multiplicity of government agencies operating on both sides of the same border doubles the bureaucracy at border posts and results in significant congestion and delays. It is estimated that the existing cumbersome procedures in customs processing can cost a consignment about $\$ 185$ for each day of delay (AUDA-NEPAD, 2020).

By magnifying Africa's cross-border inefficiencies, the COVID-19 crisis presents an opportunity to reinvigorate efforts targeted at overcoming long-standing challenges. This has increased the urgency to do better and find innovative solutions to facilitate safe and efficient cross-border trade. It will be important for Africa to maintain and upgrade these solutions post COVID-19, to lower trade costs, boost competitiveness, and support more resilient cross-border trade in the face of future shocks.

Various tools and interventions have emerged in recent years to respond to Africa's trade facilitation challenges. Many of these tools have been successfully piloted at specific borders 
or corridors. These tools can be easily tailored and extended to respond to COVID-19 border challenges, including the one-stop border post concept, the MoveAfrica traffic light system developed by AUDA-NEPAD, and regional transit guarantee schemes, as summarized below.

One-stop border posts: The one-stop border post concept refers to the legal and institutional framework, facilities and associated procedures that enable goods, people and vehicles to stop in a single facility in which they undergo necessary controls following applicable regional and national laws to exit one State and enter the adjoining State. The major reason for establishing one-stop border posts along transport corridors is to expedite the movement of goods and people, and to reduce transport costs across national boundaries. For passenger cars and buses, the introduction of one-stop border post procedures almost immediately cuts border processing time in half. Currently, more than 80 one-stop border posts have been implemented or planned in various parts of Africa as a means of reducing the time and costs of delays at border crossings along major corridors (AUDA-NEPAD, 2017). Moving forward, efforts will be required to fully operationalize one-stop border posts that have already been constructed but are not yet functional, and to roll them out across the continent. Functioning one-stop border posts can be used to coordinate the implementation of COVID-19 health checks and regulations, reducing additional time and monetary costs.

Traffic light system: The NEPAD traffic light system under the MoveAfrica programme assesses and ranks the performance of border posts, and documents corrective actions for replication to other border posts. This has helped to address some challenges faced along pilot transport and logistics corridors in the EAC, ECOWAS and SADC regions (NEPAD, 2019). The tool can be easily updated to make it COVID-19 relevant and inclusive. To this end, ECA is collaborating with AUDA-NEPAD to update and extend the tool along four lines: (1) update existing indicators to reflect specific COVID-19 border challenges; (2) include new COVID-19 health and safety indicators; (3) increase frequency of assessment to ensure timely and relevant information; and (4) regularly publish assessments and rankings on "relative" ease of movement and clearance at border posts amid COVID-19 to inform logistical planning and routes taken by truck drivers, and incentivize corrective action by authorities.

Regional transit guarantee schemes: Africa imports many goods that must transit countries with seaports as well as landlocked ones before reaching their final destination. Transit countries require that transit guarantees be provided to safeguard import duties. Currently, very few regional economic communities are fully implementing regional transit guarantee schemes, and traders are instead typically required to post national bonds at each and every border, which significantly increases the time and monetary costs of transit trade. The COMESA regional customs transit guarantee bond scheme is the most advanced on the continent: its implementation has been estimated to reduce the cost of transport and clearance by 10-15 per cent (Kasuku, 2014). The African Export-Import Bank recently launched the Africa collaborative transit guarantee scheme to allow goods to move within regional economic communities under a single transit guarantee. It also allows goods from one regional economic community to move to another under a single transit guarantee and promote intraregional trade. Eventually, it will allow for goods to move throughout the continent under a single continental bond to promote intra-African trade under the AfCFTA Agreement (African Export-Import Bank, 2020). COVID-19 offers an opportunity to fast track the rolling out of transit guarantee schemes to reduce transit costs, at the regional level and eventually at the continental level. 
Expanding implementation coverage to all regional economic communities during the pandemic would help to position these tools to become robust and sustainable instruments to support the movement of goods and services across Africa. This highlights the need for an ambitious TLS resource mobilization strategy driven by increased coordination between leading continental development partners, including ECA, AUDA-NEPAD, the African ExportImport Bank and the African Development Bank. 


\section{Conclusion and policy recommendations}

To combat COVID-19, almost all African countries, to differing degrees, have suspended international flights, introduced 14-day quarantine for entrants into countries, and closed land or maritime borders. Typically, these closures are targeted at the movement of people, and embody exemptions for the movement of emergency and essential freight supplies, under very strict conditions. This has led to an abrupt slowdown and delays in cross-border trade, and the divergence of trade to less safe unofficial routes. Disruptions to cross-border trade delay access to emergency COVID-19 supplies, increase food insecurity, and exacerbate vulnerabilities among poor households.

Since COVID-19 is a "cross-border" virus, combating the virus requires regional coordinated actions to contain the spread of COVID-19 at the same time as facilitating safe cross-border trade. COMESA, EAC and SADC have published guidelines to provide a set of standardized regulations to facilitate essential trade among their member States amid COVID-19. Other regional economic communities are in the process of developing or approving similar guidelines. Regional guidelines provide a framework to improve coordination, overcome border disputes and facilitate essential trade. COVID-19 "good-practice" in coordination and trade facilitation response measures should be retained for better facilitation in the future.

Implementation of regional-level guidelines must nevertheless take place at the national level and the rules and regulations translated and contextualized to the realities faced by individual countries. Not all countries have transitioned quickly in terms of the implementation of the existing trade facilitation guidelines of the regional economic communities. A SADC assessment of implementation of the guidelines reveals that member States are implementing trade and transportation laws and regulation differently during the COVID-19 emergency. The lack of harmonization of public health measures at border posts, such as health screening, testing, quarantine and clearance policies, means that congestion and delays at borders are still significant. This highlights the need to fast track the implementation of guidelines in a cooperative and consistent manner across all member States.

The following discussion presents a set of priority policy recommendations that will help to support the consistent implementation of regional COVID-19 trade facilitation guidelines, and enhance coordination across African regional economic communities in the context of the continent's regional integration policy underpinned by the AfCFTA Agreement. 


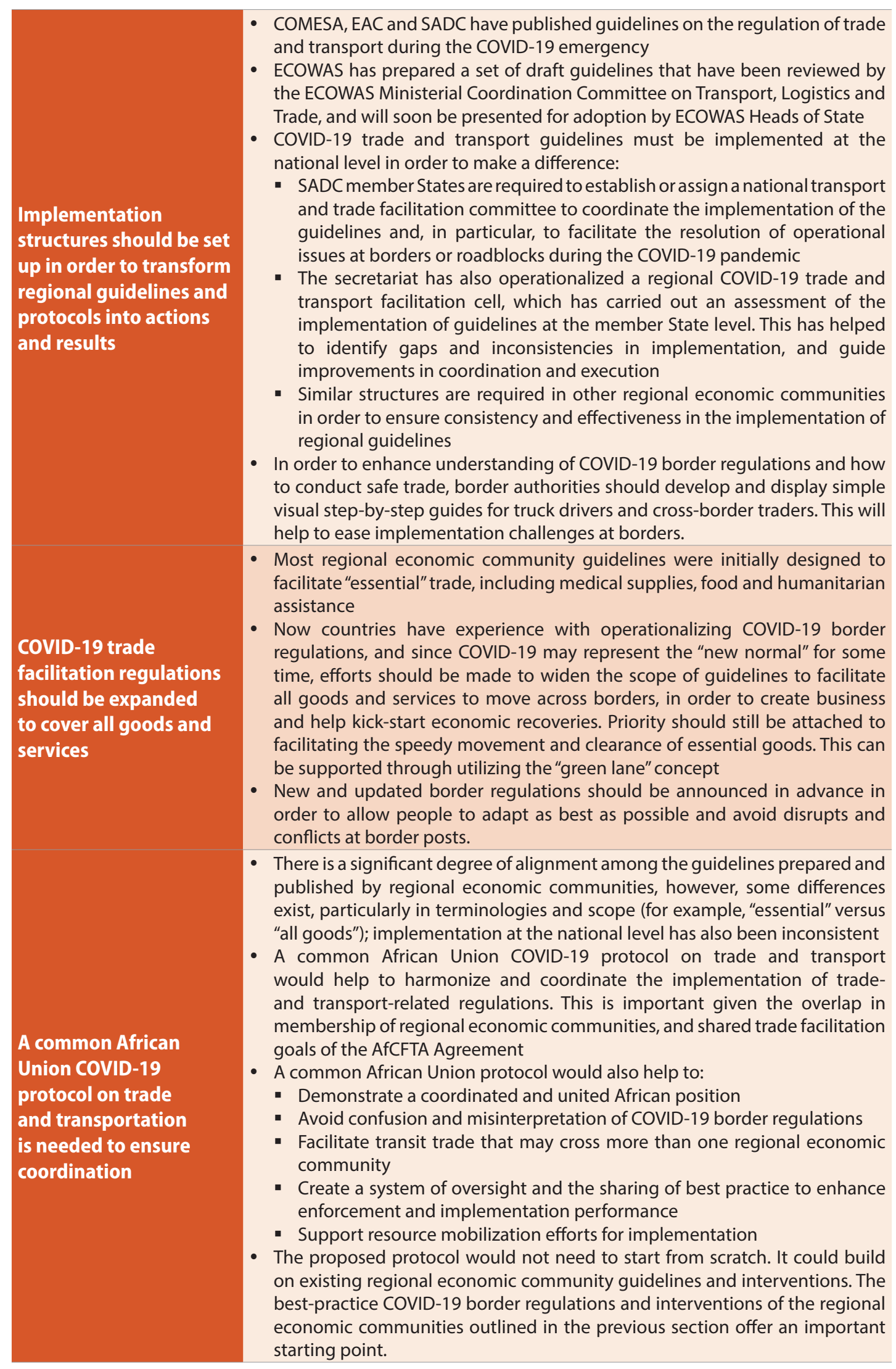




\begin{tabular}{|c|c|}
\hline $\begin{array}{l}\text { A common African } \\
\text { Union COVID-19 test } \\
\text { certificate for truck } \\
\text { drivers and crew } \\
\text { members is required }\end{array}$ & $\begin{array}{l}\text { - In East Africa, partner States have adopted the EAC COVID-19 test certificate } \\
\text { for truck drivers and crew members, to facilitate a common approach to } \\
\text { certifying results of those tested for COVID-19. This has helped to significantly } \\
\text { fast track the clearance of trucks and reduced queues at border crossings } \\
\text { - This initiative should be replicated in other regional economic communities } \\
\text { and, in order to facilitate an aligned approach, the African Union should } \\
\text { consider establishing a common African Union certificate for truck drivers } \\
\text { and crew members: } \\
\text { - The certificates generated for drivers and crew members who have } \\
\text { undergone tests can be shared with stakeholders at accredited designated } \\
\text { testing points and border crossings } \\
\text { - The certificate should be valid for } 14 \text { days, and allow the owner to travel } \\
\text { within the continent without being subjected to retesting unless he or she } \\
\text { is found to have signs and symptoms of COVID-19 upon health screening } \\
\text { at checkpoints } \\
\text { - Certificates should be issued only for those drivers and crew members that } \\
\text { test negative for COVID-19 } \\
\text { - Those who test positive must follow existing national protocols on } \\
\text { quarantining and accessing care } \\
\text { - Efforts towards new rapid testing of COVID-19 should continue in order to } \\
\text { reduce the turnaround time for test results, thereby reducing the time taken } \\
\text { to obtain a COVID-19 test certificate }\end{array}$ \\
\hline $\begin{array}{l}\text { African economies } \\
\text { should not let } \\
\text { COVID-19 undermine } \\
\text { regional integration, } \\
\text { and must maintain } \\
\text { the momentum and } \\
\text { ambition of the AfCFTA } \\
\text { process }\end{array}$ & $\begin{array}{l}\text { - In some instances, new COVID-19 border regulations and concerns of cross- } \\
\text { border transmission of the virus have caused clashes between truck drivers } \\
\text { and border authorities, and even disputes that have required diplomatic } \\
\text { intervention } \\
\text { - Amid the pandemic, African countries should not lose sight of the AfCFTA } \\
\text { Agreement: } \\
\text { - The rapid and ambitious implementation of the Agreement Establishing } \\
\text { the African Continental Free Trade Area will hasten the economic recovery } \\
\text { from the impact of COVID-19, while protecting Africa against future } \\
\text { adverse global shocks related to health, food supply and climate change, } \\
\text { and more regional shocks such as the locust crisis in East Africa } \\
\text { - Similar to the Bretton Woods Agreement, the AfCFTA Agreement can be } \\
\text { seen as an aid to rebuild African economies and promote continental } \\
\text { cooperation and solidarity in the realm of trade } \\
\text { - In order to ensure that African countries are ready to implement the AfCFTA } \\
\text { Agreement as soon as COVID-19 lifts and negotiations recommence, a } \\
\text { number of proactive preparatory actions will be required: } \\
\text { - The AfCFTA secretariat should continue its staff recruitment and } \\
\text { operationalize a fully functional online office } \\
\text { - AfCFTA negotiations should continue online, utilizing the secure electronic } \\
\text { platform offered by the AfroChampions } \\
\text { - National planning for the implementation of the AfCFTA Agreement (and } \\
\text { supporting institutions) should continue so that countries will be ready for } \\
\text { implementation once the crisis eases } \\
\text { - The African Union Commission should consider accepting electronically } \\
\text { ratified versions of the Agreement until the pandemic subsides }\end{array}$ \\
\hline
\end{tabular}


Implementation of the

WTO Trade Facilitation

Agreement and AfCFTA

Agreement Annexes

on Trade Facilitation,

Customs Cooperation

and Transit Trade should

be fast tracked

Digital solutions should

be deployed to combat

the spread of COVID-19

along trade corridors,

and support safe and

efficient trade
- COVID-19 has magnified challenges related to border operations, customs cooperation and trade facilitation

- As AfCFTA State Parties finalize tariff offers and gear up to begin trading, African countries can already start to prioritize the implementation of elements of the AfCFTA Agreement that are complete and "ready to go". Most importantly, this should include:

- Annex on trade facilitation - aims to simplify and harmonize international trade procedures and logistics to expedite the processes of importation, exportation and transit

- Annex on customs cooperation - commits State Parties to cooperate in all areas of customs administration, with the end goal of improving the regulation of trade flows and the enforcement of applicable laws

- Non-tariff barrier mechanism - built into the implementation of the Agreement to monitor, report and resolve such barriers

- These annexes should be implemented in a manner that is cognizant of the risks of unregulated movements of pathogens and hazardous goods. This is crucial to ensuring that borders are ready to manage future health crises in a safe way, so that cross-border-trade can continue to flow with limited additional costs and disruption

- The AfCFTA secretariat should prioritize its activities to support member States to fast track implementation of trade facilitation provisions

- As economies ease lockdown and travel restrictions, and revert to a "new normal" under COVID-19, coordinated action on trade facilitation will be crucial to facilitate the smooth flow of non-essential goods and kick-start the COVID-19 recovery

- EAC has a functioning electronic cargo tracking system in place, and SADC is in the process of developing one. Such systems can help to significantly reduce the spread of COVID-19 and should be replicated and made accessible across Africa

- Mobile banking and payment systems should be encouraged to facilitate a reduction in risky cash-based payments and support the control of crossborder trade through mobile lending solutions:

- The Government of Kenya issued guidelines to discourage the use of cash transactions. In response, outlets are adopting cashless policies and receive payments only via M-Pesa

- Similar guidelines should be issued in other countries and regions, and mobile companies can also promote the shift to mobile-based payments by reducing or eliminating fees

- COVID-19 has also highlighted difficulties in carrying out cross-border trade in a period where physical presence is not possible:

- Authorities should consider relaxing requirements to insist on the presentation or submission of original certificates or documents

- Copies of electronic versions of proof of compliance should be accepted in an attempt to curb the spread of COVID-19

- The upcoming AfCFTA negotiations on e-commerce should be utilized to fast-track digitalization of procedures and systems so that the continent's exporters are less at risk of losing access to markets in future crises

- Cooperation achieved to introduce digital solutions during the crisis should be leveraged to move more quickly on accelerating cashless cross-border payments and electronic systems post COVID-19 


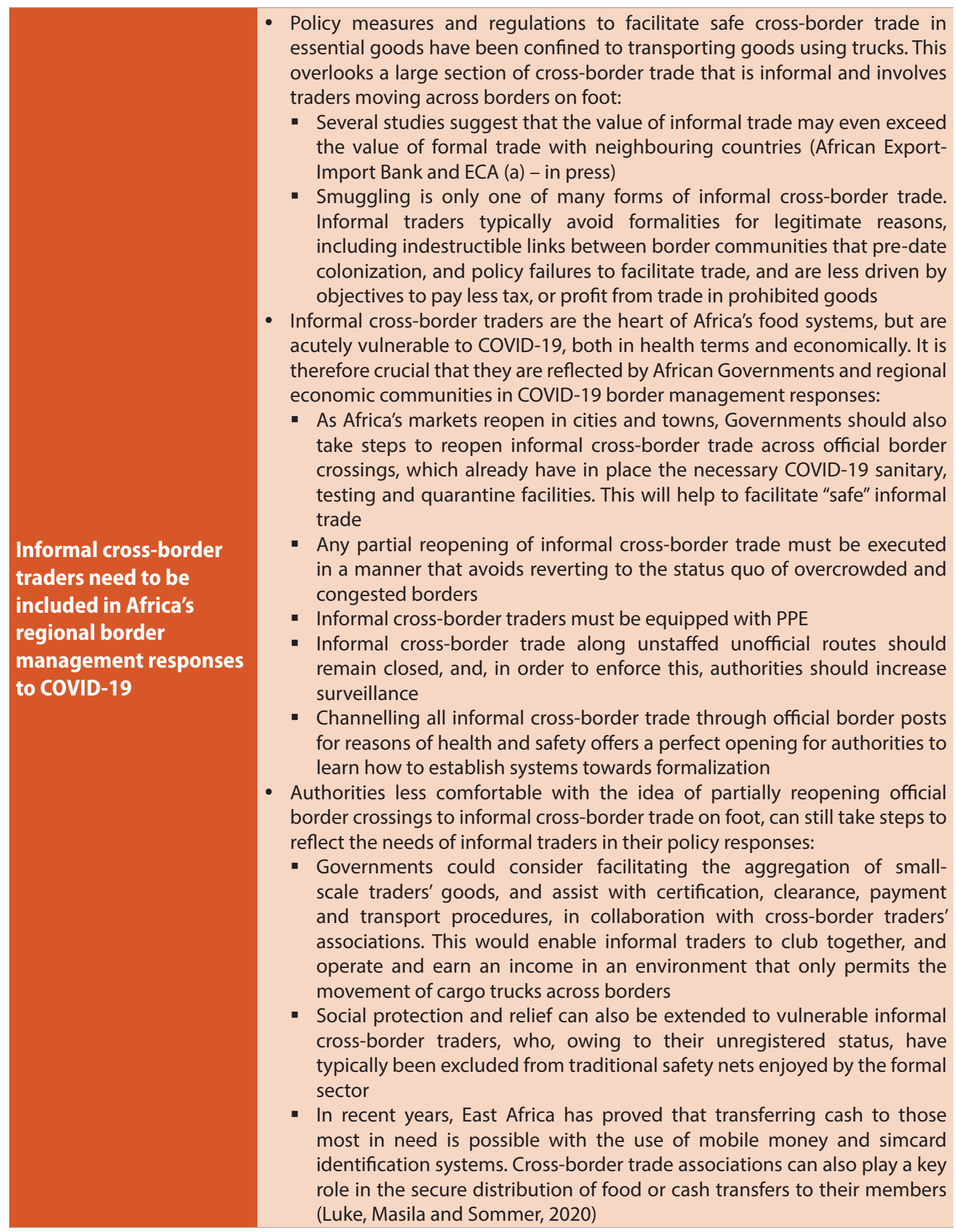




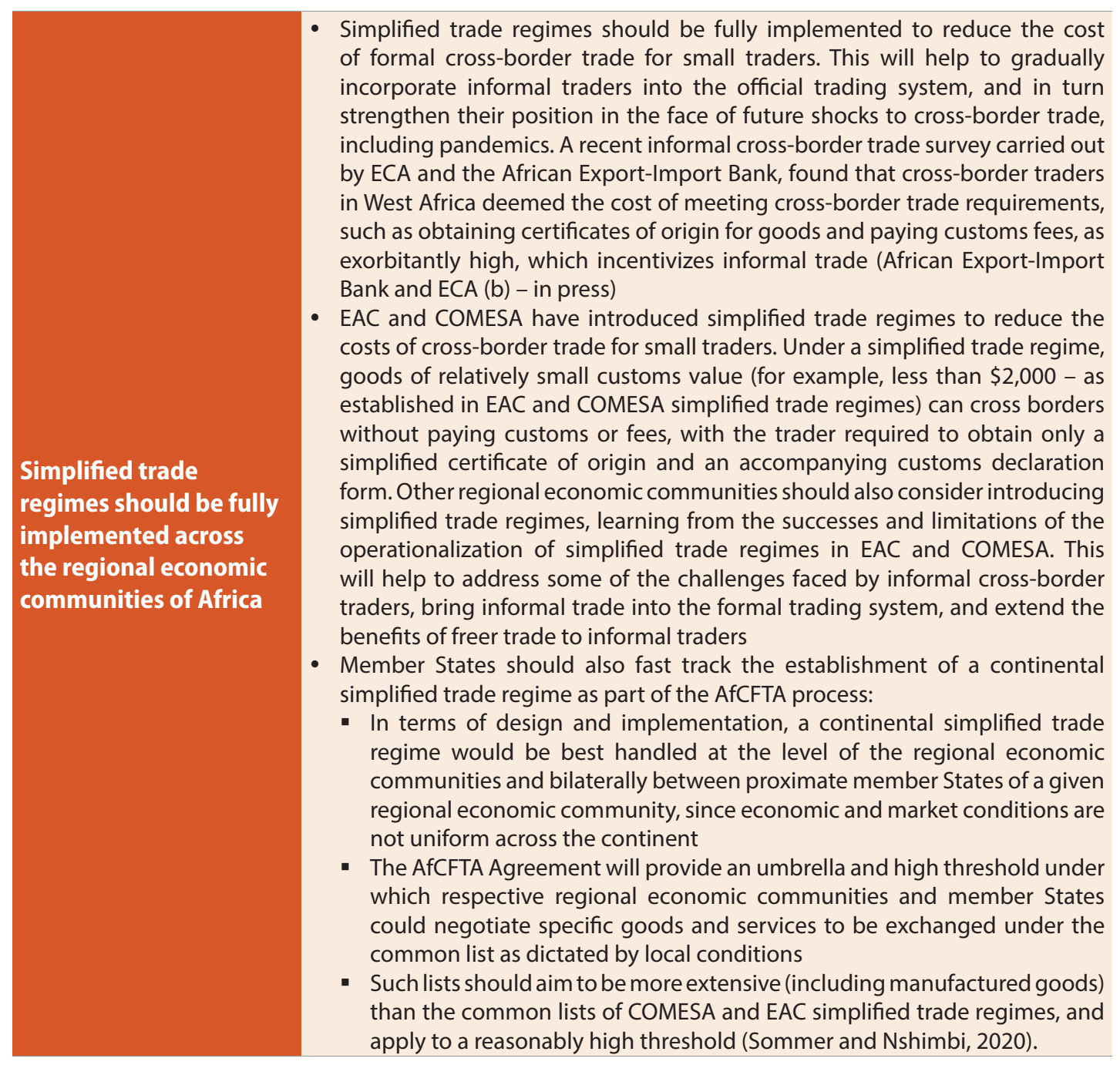




\section{Annexes}

\section{Annex I: African country exports on a monthly and quarterly basis (year-on-year percentage changes), 2020 versus 2019}

\begin{tabular}{|c|c|c|c|c|c|}
\hline Country & January & February & March & Quarter 1 & April \\
\hline Algeria & 26.85 & -33.16 & -35.27 & -16.12 & -49.74 \\
\hline Angola & 83.61 & -12.03 & -31.30 & 6.69 & -49.97 \\
\hline Benin & -33.00 & -30.88 & -9.08 & -25.28 & -48.79 \\
\hline Botswana & 4.74 & -12.70 & -7.82 & -5.58 & -30.48 \\
\hline Burkina Faso & 32.38 & -39.57 & 11.19 & 6.34 & -32.52 \\
\hline Cameroon & -2.85 & 20.62 & 16.30 & 10.72 & -51.10 \\
\hline Central African Republic & -4.23 & -5.95 & 1.08 & -3.13 & 3.45 \\
\hline Chad & 39.57 & 12.31 & -86.72 & -35.18 & -53.99 \\
\hline Comoros & -8.59 & -59.94 & 151.63 & -14.35 & -55.35 \\
\hline Congo & 29.53 & 12.26 & -15.49 & 7.89 & 49.61 \\
\hline Côte d'Ivoire & -10.29 & 1.21 & -10.88 & -7.01 & 1.89 \\
\hline Djibouti & -2.98 & -8.58 & -13.43 & -8.26 & -2.53 \\
\hline Egypt & 8.39 & -3.14 & -12.52 & -2.95 & -15.77 \\
\hline Equatorial Guinea & 0.09 & -17.42 & 45.29 & 4.24 & -64.65 \\
\hline Ethiopia & -3.76 & 28.69 & -14.01 & 1.51 & 6.45 \\
\hline Gabon & -64.69 & -5.23 & -9.16 & -25.90 & -25.90 \\
\hline Gambia & -61.92 & 98.30 & 54.47 & 2.97 & 101.87 \\
\hline Ghana & 58.42 & 22.10 & -21.44 & 16.04 & 16.90 \\
\hline Guinea & -35.79 & -63.95 & -0.64 & -32.32 & -21.62 \\
\hline Guinea-Bissau & -23.77 & 43.99 & -17.99 & -6.54 & 101.94 \\
\hline Kenya & 10.64 & -0.01 & -7.93 & 0.99 & -2.82 \\
\hline Lesotho & 11.55 & 51.76 & 0.90 & 19.00 & -45.26 \\
\hline Madagascar & 19.03 & 9.04 & -0.41 & 9.39 & -7.89 \\
\hline Malawi & -37.79 & -15.99 & -1.00 & -20.11 & -19.63 \\
\hline Mauritania & 21.12 & -31.74 & 26.28 & 1.37 & 14.77 \\
\hline Mauritius & -13.87 & -20.33 & 4.33 & -9.56 & -33.51 \\
\hline Morocco & -53.65 & -52.25 & -62.42 & -56.62 & -52.25 \\
\hline Mozambique & -33.81 & -23.58 & -13.24 & -24.21 & -3.72 \\
\hline Namibia & 35.62 & 0.01 & -17.16 & 5.11 & -34.04 \\
\hline Nigeria & -7.14 & -0.54 & -27.58 & -12.02 & -56.96 \\
\hline Rwanda & -15.24 & -7.02 & 15.06 & -5.92 & -6.01 \\
\hline Sao Tome and Principe & 31.21 & 28.34 & -1.00 & 18.21 & 64.89 \\
\hline Sierra Leone & 7.90 & 2.41 & 1.88 & 4.13 & 46.86 \\
\hline South Africa & 7.19 & -0.73 & -6.11 & -0.17 & -16.41 \\
\hline Togo & -50.28 & 93.72 & 12.13 & 12.52 & 4.10 \\
\hline Tunisia & -8.24 & 3.20 & -12.51 & -6.15 & -70.58 \\
\hline Uganda & 10.92 & -0.31 & -52.09 & -26.14 & 2.49 \\
\hline Zambia & -22.44 & -11.64 & -26.13 & -20.45 & -20.11 \\
\hline Zimbabwe & -9.31 & -16.68 & -24.12 & -17.08 & -22.48 \\
\hline
\end{tabular}

Source: Data from UNCTAD are based on national statistics from 2019 and 2020. Statistics are preliminary and based on a limited number of countries. 


\section{Annex II: African country imports on a monthly and quarterly basis (year-on-year percentage changes), 2020 versus 2019}

\begin{tabular}{|c|c|c|c|c|c|}
\hline & January & February & March & Quarter 1 & April \\
\hline Algeria & -16.29 & -1.58 & -13.75 & -11.06 & -25.26 \\
\hline Angola & -13.99 & -17.74 & -15.78 & -15.75 & -32.28 \\
\hline Benin & -61.47 & -38.25 & -57.19 & -53.85 & -37.91 \\
\hline Botswana & -4.23 & -3.06 & -7.08 & -4.88 & -31.83 \\
\hline Burkina Faso & -4.26 & -17.65 & -13.72 & -12.34 & -5.54 \\
\hline Cameroon & 5.43 & 13.53 & 1.51 & 6.52 & -13.76 \\
\hline Central African Republic & -7.03 & 59.70 & -12.25 & 11.46 & 10.00 \\
\hline Chad & 21.79 & 15.90 & 31.89 & 23.75 & -12.99 \\
\hline Comoros & -19.23 & 2.37 & -30.89 & -17.15 & -31.41 \\
\hline Congo & -33.12 & -28.49 & -8.14 & -22.85 & -26.88 \\
\hline Côte d'Ivoire & 1.57 & 12.28 & -6.94 & 1.81 & -22.55 \\
\hline Djibouti & -25.37 & 34.19 & -33.28 & -14.70 & -31.05 \\
\hline Egypt & 6.05 & -7.67 & -4.53 & -2.17 & -16.38 \\
\hline Equatorial Guinea & -8.23 & -23.22 & 27.94 & -2.03 & -33.41 \\
\hline Ethiopia & -0.15 & -4.42 & 54.52 & 16.83 & -34.59 \\
\hline Gabon & 1.83 & 0.03 & -12.04 & -3.85 & -22.04 \\
\hline Gambia & -3.71 & -16.26 & -11.28 & -10.45 & -12.01 \\
\hline Ghana & 2.91 & -5.64 & 9.51 & 2.58 & -11.40 \\
\hline Guinea & -11.16 & 15.62 & 2.27 & 2.80 & 15.52 \\
\hline Guinea-Bissau & 10.08 & 4.03 & 100.83 & 28.62 & -29.61 \\
\hline Kenya & 0.75 & -6.45 & -14.86 & -7.06 & -13.19 \\
\hline Lesotho & 8.52 & 8.16 & -5.40 & 3.62 & -10.44 \\
\hline Madagascar & 3.13 & 21.80 & 5.22 & 9.20 & -20.74 \\
\hline Malawi & -23.97 & -13.68 & -20.14 & -19.21 & -15.16 \\
\hline Mauritania & -20.47 & 32.81 & 1.84 & 3.50 & -30.33 \\
\hline Mauritius & -0.37 & -14.38 & 1.21 & -4.67 & -35.62 \\
\hline Morocco & -3.82 & 0.24 & -18.77 & -8.09 & -40.13 \\
\hline Mozambique & 4.44 & 18.79 & 0.73 & 7.97 & -7.69 \\
\hline Namibia & -26.56 & -17.71 & -21.33 & -21.91 & -25.75 \\
\hline Nigeria & 1.18 & 32.35 & 7.57 & 11.95 & -28.79 \\
\hline Rwanda & 25.53 & -6.60 & 27.91 & 14.97 & -9.08 \\
\hline Sao Tome and Principe & 1.94 & -2.65 & 17.60 & 6.02 & -41.02 \\
\hline Sierra Leone & -38.25 & 5.44 & -14.97 & -17.41 & -17.97 \\
\hline South Africa & -0.30 & -6.62 & -16.37 & -7.91 & -30.25 \\
\hline Togo & -13.01 & -8.48 & -15.40 & -12.48 & -9.20 \\
\hline Tunisia & 9.06 & 0.86 & -20.66 & -4.29 & -44.73 \\
\hline Uganda & 10.65 & 15.97 & -2.18 & 7.30 & -9.17 \\
\hline Zambia & 6.66 & 2.69 & 1.51 & 3.53 & -12.69 \\
\hline Zimbabwe & 19.88 & 9.80 & -8.82 & 5.73 & -6.29 \\
\hline
\end{tabular}

Source: Data from UNCTAD are based on national statistics from 2019 and 2020. Statistics are preliminary and based on a limited number of countries. 


\section{References}

African Export-Import Bank, "African collaborative transit guarantee scheme”, flyer, 2020.

African Export-Import Bank and Economic Commission for Africa (a), "Informal cross-border trade in Africa", thematic chapter in the 2020 AFREXIMBANK Africa trade report (in press).

(b), "Enhancing the quality of informal cross-border trade in the economic community of West African States" (in press).

African Union, International Office for Migration, United Nations Children's Fund and World Health Organization (2020). Harmonized Sub-Regional Essential Infection, Prevention and Control (IPC) services at Points of Entry and within-country IPC Interventions for Transnational Truck Drivers within East African Community. Available at www.afro.who.int/sites/default/ files/Covid-19/Techinical\%20documents/Harmonized\%20Sub-Regional\%20Essential\%20 Infection\%20Prevention\%20and\%20Control\%20services\%20at\%20Points\%20of\%20Entry\%20 and\%20within-country\%20IPC\%20Interventions\%20for\%20Transnational\%20Truck\%20 Drivers\%20within\%20East\%20African\%20Community.PDF

African Union Development Agency-New Partnership for Africa's Development (2017). One-Stop Border Post (OSBP) Sourcebook, 2nd edition. Available at www.tralac.org/news/ article/11453-one-stop-border-post-osbp-sourcebook-2nd-edition.html

July 2020 .

,Work on one-stop border posts in Africa", presentation delivered to ECA on 13

AfroChampions (2020). Africa Year Zero Report: An Assessment of African Governments' Commitment and Readiness for AfCFTA Start of Trading in Light of COVID-19. Available at www. tralac.org/news/article/14574-afcfta-year-zero-report-by-the-afrochampions-initiative.html

Alliance for a Green Revolution in Africa (2020). Food Security Monitor: Africa Food Trade and Resilience Initiative. Nairobi: AGRA. Available at https://agra.org/wp-content/uploads/2020/06/ Food-Security-Monitor_No3-May-2020.pdf

Al-Aees, Shaimaa, "COMESA adopts guidelines for cross-border movement of essential goods, services", Daily News Egypt, 2 June 2020. Available at www.dailynewssegypt.com/2020/06/02/ comesa-adopts-guidelines-for-cross-border-movement-of-essential-goods-services/

Anami, Luke, "EAC agrees to deploy mobile lab test kits at borders", The East African, 2 May 2020. Available at www.theeastafrican.co.ke/news/ea/EAC-agrees-to-deploy-mobile-lab-test-kits-atborders/4552908-5540204-vee3vvz/index.html

Barigaba, Julius, "COMESA bond scheme speeds up movement of goods in Northern Corridor", The East African, 13 October 2014. Available at https://www.tralac.org/news/article/6410comesa-bond-scheme-speeds-up-movement-of-goods-in-northern-corridor.html 
Bizimungu, Julius, "COVID-19: 10 takeaways from EAC Heads of State”, online meeting, The New Times, 14 May 2020. Available at www.newtimes.co.rw/news/covid-19-10-takeaways-eacheads-state-virtual-meeting

Blandy, Fran, "Coronavirus creeps along East Africa's trucking corridors", The Citizen, 13 May 2020. Available at https://citizen.co.za/news/news-africa/2283740/coronavirus-creeps-alongeast-africas-trucking-corridors/

Bosch, Emile, "Continued COVID-19 lockdown sees rampant smuggling and desperation at border with Zimbabwe", Times Live, 22 June 2020. Available at www.timeslive.co.za/news/ south-africa/2020-06-22-watch-continued-covid-19-lockdown-sees-rampant-smugglingdesperation-at-border-with-zimbabwe/

Chiguvare, Bernard, "Truckers wait days to cross border into Zimbabwe", Ground Up, 4 June 2020. Available at www.groundup.org.za/article/truckers-wait-days-cross-border-zimbabwe/

Common Market for Eastern and Southern Africa (2020a), "COVID-19 emergency kit sent to border personnel and traders", 24 May 2020. Available at www.comesa.int/covid-19-emergencykit-sent-to-border-personnel-and-traders/

(2020b). Guidelines for the Movement of Goods and Services Across COMESA Region During the COVID-19 Pandemic, 10 June 2020. Available at www.comesa.int/wpcontent/uploads/2020/06/Guidelines-for-the-Movement-of-Goods-Services-Across-COMESARegion.pdf

(2020c). Guidelines on Free Movement of People and Goods, 10 June 2020. Available at www.comesa.int/guidelines-on-movement-of-goods-and-services-in-comesa-region/

(2020d), "Region adopts common guidelines for safe trade during COVID-19", 16 May 2020. Available at www.comesa.int/comesa-minister-meet-agree-to-develop-an-onlineinformation-exchange-platform-to-facilitate-trade-in-the-time-of-covid-19/

(2020e), "Small cross border traders adopt new business tactics to manage pandemic restrictions", 25 May 2020. Available at www.comesa.int/covid-19-small-cross-border-tradersadopt-new-business-tactics/

East African Community (2020a). East African Community Administrative Guidelines to Facilitate Movement of Goods and Services during the COVID-19 Pandemic. Available at www.eac.int/ covid-19

(2020b), "EAC secretariat to deploy mobile laboratories and testing kits and to all partner States in a bid to mitigate coronavirus", press release, 23 March 2020. Available at www.eac.int/press-releases/1704-eac-secretariat-to-deploy-mobile-laboratories-and-testingkits-and-to-all-partner-states-in-a-bid-to-mitigate-coronavirus

(2020c), "EAC partner States adopt the EAC Regional Electronic Cargo and Drivers Tracking System", press release, 30 May 2020. Available at www.eac.int/press-releases/147health/1736-eac-partner-states-adopt-the-eac-regional-electronic-cargo-and-driverstracking-system 
Eastern Africa Grain Council (2020a), "Weekly update on the COVID-19 pandemic for the grain sector in Eastern Africa", 1 June 2020. Available at http://eagc.org/wp-content/uploads/2020/06/ EAGC-COVID-19-COMMUNIQUE-Release-No.-10-1.pdf

(2020b), "Weekly update on the COVID-19 pandemic for the Grain Sector in Eastern Africa", 18 May 2020. Available at http://eagc.org/wp-content/uploads/2020/05/EAGC-COVID19-COMMUNIQUE-Release-No.-8.pdf

Economic and Social Commission for Asia and the Pacific, "UN seeks to build transport and trade resilience in wake of COVID-19", press release, 28 May 2020. Available at www.unescap. org/news/un-seeks-build-transport-and-trade-resilience-wake-covid-19

Economic CommunityofWestAfricanStates(2020a),"COVID-19:ECOWASMinisterialCoordinating Committee recommends gradual and coordinated opening of borders", 18 June 2020. Available

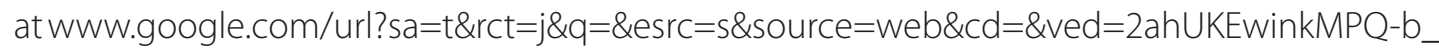
qAhVWUhUIHZPmCKQQFjAAegQIBRAB\&url=https\%3A\%2F\%2Fwww.tralac.org\%2Fdocument s\%2Fresources\%2Fcovid-19\%2Fregional\%2F3748-covid-19-ecowas-ministerial-coordinatingcommittee-recommends-gradual-and-coordinated-opening-of-borders-18-june-2020. html\&usg=AOvVaw0dXvY3pta31_K75Ca4ieO-

(2020b), “ECOWAS Committee of Experts meet on ease of trade during COVID-19 period", 9 June 2020. Available at www.ecowas.int/ecowas-committee-of-experts-meet-onease-of-trade-during-covid-19-period/

Harmonization and facilitation of cross-border trade and transport in the ECOWAS Region on the COVID-19 pandemic and related post-recovery actions. Draft (in press).

International Food Policy Research Institute, "COVID-19 border policies create problems for African trade and economic pain for communities", 12 May 2020. Available at www.ifpri.org/blog/ covid-19-border-policies-create-problems-african-trade-and-economic-pain-communities

Luke, David, Gerald Masila and Lily Sommer, "Informal traders: a balancing act of survival", Economic Commission for Africa, 12 May 2020. Available at www.uneca.org/sites/default/files/ PublicationFiles/informal_traders___a_balancing_act_of_survival_eng_3.pdf

New Partnership for Africa's Development, "Traffic light system pilot process commences in ECOWAS", 23 May 2019. Available at www.nepad.org/news/traffic-light-system-pilot-processcommences-ecowas

Poverello, Mike, "SADC set to reopen cross-border trade", 31 May 2020. Available at https:// mpoverello.com/2020/05/31/sadc-set-to-reopen-cross-border-trade/

Sabiiti, Daniel, "EAC agrees on harmonized COVID-19 cross border testing plan", KT Press, 11 May 2020. Available at www.ktpress.rw/2020/05/eac-agrees-on-harmonized-covid-19-crossborder-testing-plan/

Southern African Development Community (2020a). Bulletin No.6: Report on the COVID-19 Pandemic in the SADC Region with a Specific focus on its Impact on Fisheries and Aquaculture Value Chains. Available at www.sadc.int/files/4815/9142/3100/BULLETIN_6-SADC_Response_ to_COVID19_ENGLISH.pdf 
(2020b). Regional Food Security Update - January to March 2020. Issue 2. April 2020. Available at www.sadc.int/files/3515/9066/3427/SADC_Food_and_Nutrition_Security_ Update_Issue-03_-_2019_-_2020.pdf

(2020c). Regional standard operating procedures for management and monitoring of cross border road transport at designated points of entry and COVID-19 checkpoints. 23 June 2020. Available at www.google.com/ url? sa $=t \& r c t=j \& q=\& e s r c=s \& s o u r c e=w e b \& c d=\& v e d=2$ a hUKEwi 6 ufn $9 \_$_ qAhVdZxUIHY7fDQEQFjAAegQIBhAB\&url=https\%3A\%2F\%2Fwww.tralac.org\%2Fdocum ents\%2Fresources\%2Fcovid-19\%2Fregional\%2F3783-sadc-regional-standard-operatingprocedures-for-management-and-monitoring-of-cross-border-road-transport-at-designatedpoints-of-entry-and-covid-19-checkpoints-23-june-2020.html\&usg=AOvVaw1 mG2CtGdO1pNEn20F3yWH

(2020d). Revision No. 1:SADC Guidelines on Harmonisation and Facilitation of Cross Border Transport Operations across the Region During the COVID-19 Pandemic. 23 June 2020. Available at www.google.com/url? sa $=t \& r c t=j \& q=\& e s r c=s \&$ source $=$ web\&cd $=\& v e d=2 a h U K E w$ jj6-aZ_b_qAhWStXEKHTctDvQQFjAAegQIBBAB\&url=https\%3A\%2F\%2Fwww.tralac.org\%2Fdo cuments\%2Fresources\%2Fcovid-19\%2Fregional\%2F3782-sadc-guidelines-on-harmonisationand-facilitation-of-cross-border-transport-operations-across-the-region-during-the-covid-19pandemic-revision-23-june-2020.html\&usg=AOvVaw16PJRiSUXZ4fx32rBPQVmA

(2020e). SADC adopts regional guidelines for harmonising and facilitating movement of critical goods and services across the region during the COVID-19. 6 April 2020. Available at www.sadc.int/news-events/news/sadc-adopts-regional-guidelines-harmonisingand-facilitating-movement-critical-goods-and-services-across-region-during-covid-19/

(2020f). SADC Guidelines on Harmonisation and Facilitation of Cross Border Transport Operations across the Region During the COVID-19 Pandemic. 6 April 2020. Available at www.sadc.int/files/8315/8626/0246/Final_SADC_Guidelines_on_Cross-Border_Transport_ during_COVID19-Adopted_on_6_April_2020-ENGLISH.pdf

Slater, D. (2020). Zimbabwe border fence completed. Engineering News, 4 May 2020. Available at https://m.engineeringnews.co.za/article/zimbabwe-border-fence-completed-2020-05-04/ rep_id:4433

Lily Sommer and Nshimbi, C. (2020). The African Continental Free Trade Area: An Opportunity for Informal Cross-border Trade. 11 June 2018 in ICTSD's Bridges Africa. Available at http:// governanceinnovation.org/the-african-continental-free-trade-area-an-opportunity-forinformal-cross-border-trade-by-lily-sommer-and-chris-nshimbi/

Thsuma, E. (2020). Coronavirus and freight forwarding in SADC. 9 April 2020. Available at www. tralac.org/blog/article/14502-coronavirus-and-freight-forwarding-in-sadc.html

Trade MarkEast Africa (2020). Impacts of COVID-19 on Eastern AfricaTrade, Transit and Borders, 4-8 May 2020. Available at www.trademarkea.com/wp-content/uploads/dlm_uploads/2020/05/ TMEA-COVID-19-Trade-and-Transit-Border-Update-4-8th-May.pdf

United Nations Conference on Trade and Development (2020). Global Trade Update, June 2020. Available at https://unctad.org/en/PublicationsLibrary/ditcmisc2020d2_en.pdf 
Wasike, Andrew, "East African truckers face backlash from COVID-19", Anadolu Agency, 17 May 2020. Available at www.aa.com.tr/en/africa/east-african-truckers-face-backlash-fromcovid-19/1843735.

World Customs Organization and International Road Transport Union, "Responding to the impacts of COVID-19 on cross-border transport", joint statement, 12 May 2020. Available at www.wcoomd.org/en/media/newsroom/2020/may/joint-wco-iru-statement-on-respondingto-the-impacts-of-covid-19-on-cross-border-transport.aspx

World Food Programme, "WFP Kenya Country Office COVID-19 supply chain and markets update", 5 June 2020. Available at https://reliefweb.int/report/kenya/wfp-kenya-covid-19supply-chain-and-markets-update-5-june-2020

World Health Organization, "Updated WHO recommendations for international traffic in relation to COVID-19 outbreak", 29 February 2020. Available at www.who.int/news-room/articles-detail/ updated-who-recommendations-for-international-traffic-in-relation-to-covid-19-outbreak 